\begin{tabular}{|c|c|c|}
\hline \multirow{2}{*}{$\underline{\text { DE }}$} & DE GRUYTER & ECONOMIC THEMES (2015) 53 (4): 547-581 \\
\hline & & DOI 10.1515/ethemes-2015-0032 \\
\hline
\end{tabular}

\title{
STATE AND ANALYSIS OF SCIENTIFIC JOURNALS IN THE FIELD OF "ECONOMIC SCIENCES" FOR THE PERIOD 1995-2014
}

\author{
Predrag Dašić \\ SaTCIP Publisher Ltd. Vrnjačka Banja, Serbia \\ $\bowtie$ dasicp58@gmail.com
}

UDC

655.3.066.13:33

"1995/2014"

Review paper
Received:

12.11.2015

Accepted:

17.12.2015

\begin{abstract}
SCI-E and SSCI are one of the main citation databases (CDB) in the world in the field of natural and applied (SCI-E) and social (SSCI) scientific disciplines. In 2014, within the SCI$\mathrm{E}$ all scientific fields of natural and applied science disciplines are classified into 176 categories, and within SSCI all scientific fields of social science disciplines are classified into 56 categories. Scientific journals in the field of "Economic Sciences" are sorted within the SSCI in 8 (eight) categories, plus one category within the SCI-E. The aim of the paper is to show the state and analysis of scientific journals indexed in SSCI and SCI-E citation databases (CDB) for 9 (nine) listed categories in the field of "Economic Sciences" for the period 1995-2014. The number of different scientific journals for 9 (nine) listed categories in the field of "Economic Sciences" for a period of 1997-2014, increased for 455 journals (from 415 journals in 1995 to 860 journals in 2014) with cumulative growth index (CGI) of 207,23\% compared to 1997. Best ranked category among the nine listed categories in the field of "Economic Sciences" was the category "Economics" (Econ), which according to the number of journals for the entire period 1995-2014 was always ranked first (top-one) within SSCI. The largest increase in the number of scientific journals for the period 1995-2014 for all nine listed categories in the field of "Economic Sciences" had the category "Management" (Manag).
\end{abstract}

Keywords: Bibliometric analysis, citation database (CDB), Social Science Citation Index (SSCI), Journal Impact Factor (JIF), "Economic Sciences".

\section{Introduction}

"Economic sciences" belong to the group of social and humanistic sciences, which aims to portray the factors that regulate the production, distribution and consumption of goods and services. This category can be described as the study 
of the use of resources in applied and theoretical aspects. Resources include the time and abilities of people, land, buildings, equipment, tools, materials and knowledge of how to combine the given resources to create useful products and services. "Economic sciences" also include the study of labor, investment, money and state economic regulation. Economists tend to assess the quality of life, to realize how it can increase over time, and to evaluate the quality of life of the rich and the poor. "Economic Sciences" focus on the behavior and interaction of decision-making in the model of some aspects of the economy and the overall functioning of the economy (Caplin, 2008).

The main fields of "Economic Sciences" are: microeconomics, macroeconomics, political economy, the economics of agriculture, world trade and markets, trade, studies of development of domestic and world markets, entrepreneurship, regional economic development, consulting, marketing and advertising, economic forecasting, organizational studies, compensation, strategy, retail, consumer research, business history, business ethics, accounting, finance, financial management, investments, investment strategies, international monetary system, insurance, taxes, banking, security, market, business and labor law, human resources (HR), labor relations, sociology of labor relations, international relations, management, science of management, organizational studies, strategic management, strategic planning, decision-making theory, systems for decision-making, decision-making methods (DMM), decision support systems (DSS), leadership, total quality management (TQM), operational research (OR), mathematical modeling, stochastic modeling, optimization theory, logistics, control theory, econometrics, time series analysis, time series modeling, qualitative and quantitative methods which are especially significant for the field of "Economic Sciences" are planning and development, development studies, planning theory, political and development strategies, administration, public administration, the relationship between the public and private sectors, public finance policy, training and education related to modern business economy and the field of "Economic Sciences" and etc.

\section{Citation Databases (CDB)}

There is a famous old saying that says: "It does not matter how much you jumped, but how much it was measured". It is similar in science: "It does not matter how great is your scientific contribution, but how that is how much it has been rated". In the world one of the most significant contributions to the science are the publications in scientific reference journals indexed in well-known citation databases $(\mathrm{CDB})$ in the world.

The following is an attempt to explain the citation databases (CDB), to describe methods for determining the Journal Impact Factor (JIF) and to name 
other bibliometric indicators for evaluating journals, states, regions, universities, colleges, departments and individuals.

Citation database (CDB) or reference or bibliographic database is a collection of bibliographic and citation data about: an article (the article title, authors, authors' institutions, abstract, keywords), basic information about an article in the journal (volume or year of publication of the journal, year and/or month of publication, number of pages), the article reference, citations, indexed journals (basic information about the journal, the publisher, ISSN number), computed bibliometric indicators for the article, the authors of the article and the scientific journals indexed in the database (DB), Rank in Category (RIC) and etc.

The most famous citation databases (CDB) in the world are those that are referred by the company of Thomson Reuters Corp. (TR); (Web site: $\mathrm{http} / /$ www.thomsonreuters.com/), previously known as Institute for Scientific Information (ISI).

Depending on the field of scientific disciplines the company of Thomson Reuters Corp. refers the following three citation databases (CDB):

- SCI (Science Citation Index) and SCIE (Science Citation Index, Expanded) citation databases (CDB) in the field of natural and applied scientific disciplines (available at the Web page: http://thomsonreuters.com/sciencecitation-index-expanded/) (Andreis, Jokić, 2008; Buchanan, 2007; Dašić, 2013a; Dašić, 2015b; Fu, Ho, 2013; Ho, 2013; Ma et al., 2011; Zibareva, Soloshenko, 2011),

- SSCI (Social Sciences Citation Index) citation database (CDB) for the field of social scientific disciplines (available at Web page: http://thomsonreuters.com/social-sciences-citation-index/) (Dašić, 2013b; Dašić, 2015a; Herubel, Buchanan, 1993; Huang, 2009; Leydesdorff, 2004; Moh, Lu, Lin, 2012; Su et al., 2001; Zhiren, 2002) and

- A\&HCI (Arts \& Humanities Citation Index) citation database (CDB) for the field of art and humanistic scientific disciplines (available at Web page: http://thomsonreuters.com/arts-humanities-citation-index/).

SCI covers approximately $25-30 \%$ of scientific journals in the field of natural and applied scientific disciplines. Other indexed scientific journals in the field of natural and applied scientific disciplines are included within the SCI-E citation database (CDB).

Since SCI and SCI-E are so to speak the same citation databases (CDB), the company of Thomson Reuters Corp. in all their reports, denotes both of the specified citation databases (CDB) as SCI-E (Figure 1). Also, all the authors who analyze the SCI and SCI-E citation databases (CDB), in their papers, also denote both of the specified citation databases (CDB) as SCI-E (Buchanan, 2007; Dašić, 2013; Fu, Ho, 2013; Ho, 2013). 
This base was originally created by Eugene Garfield in 1955 (Garfield, 1955) and explained in his papers (Garfield, 1970; Garfield, 1972; Garfield, 2006; Garfield, Sher, 1963; Garfield, Welljams-Dorof, 1992). It was officially launched in 1964, for information about scientific journals in 1963 and included references from 1961 and 1962. It was originally produced by the Institute for Scientific Information (Institute for Scientific Information - ISI), now owned by the company of Thomson Reuters Corp. Initially in SCI and SCI-E citation databases (CDB) there were approximately 600 scientific journals included, while in 2014 there were 8659 scientific journals included in the field of natural and applied scientific disciplines. While initially in the SSCI citation database (CDB) there were approximately 200 scientific journals, in 2014 there were 3154 scientific journals included in the field of social science disciplines.

Figure 1 Example of the Journals Citation Reports (JCR) Window with Information about Journals within the SCI-E Citation Database (CDB)

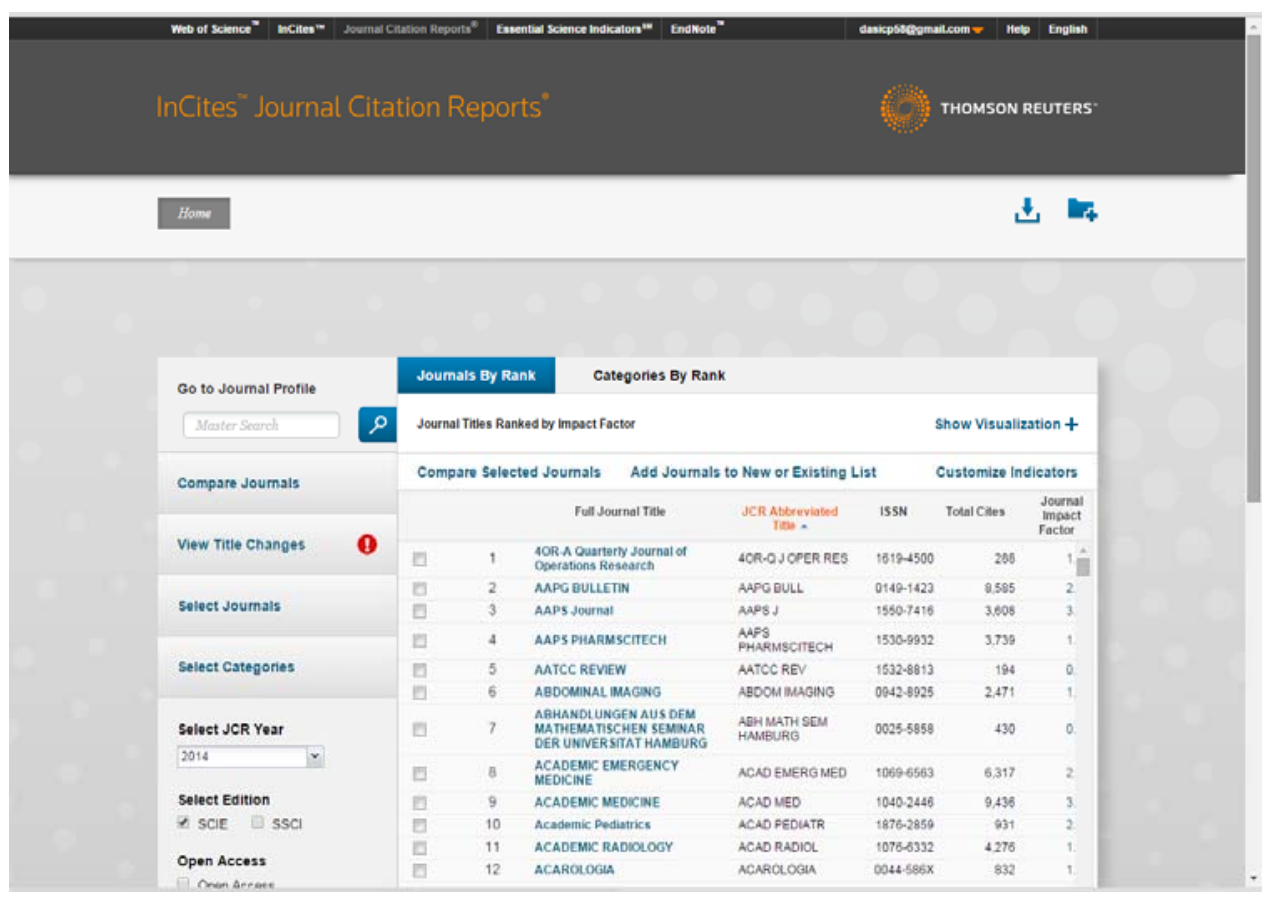

Table 1 shows the number of journals (NoJ) indexed in the SCI-E and SSCI citation databases (CDB) for the period 2005-2014, which is graphically presented in Figure 2.

Within the SCI-E and SSCI citation databases (CDB) all scientific disciplines are divided into categories or fields. Within the SCI-E citation database (CDB), for 2014, there were 8659 scientific journals indexed, divided into 176 categories. 
Table 1 Tabular Overview of the Number of Journals (NoJ) Indexed in the SCI-E and SSCI Citation Databases (CDB) for the Period 2005-2014

\begin{tabular}{|c|c|c|}
\hline Year & SCI-E & SSCI \\
\hline 2005 & 6088 & 1747 \\
\hline 2006 & 6166 & 1768 \\
\hline 2007 & 6426 & 1866 \\
\hline 2008 & 6620 & 1985 \\
\hline 2009 & 7387 & 2257 \\
\hline 2010 & 8073 & 2731 \\
\hline 2011 & 8336 & 2966 \\
\hline 2012 & 8471 & 3047 \\
\hline 2013 & 8539 & 3080 \\
\hline 2014 & 8659 & 3154 \\
\hline
\end{tabular}

Figure 2 Graphical Presentation of the Number of Journals (NoJ) Indexed in the SCI-E and SSCI Citation Databases (CDB) for the Period 2005-2014

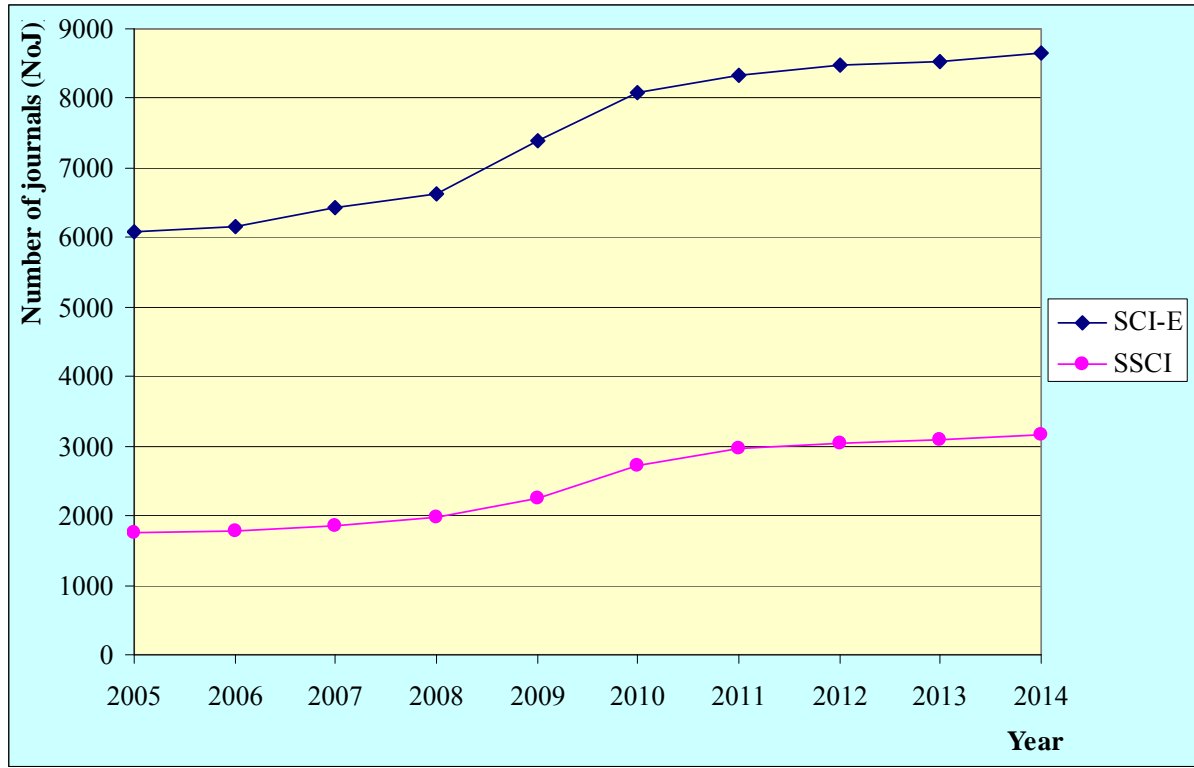

Within the SSCI citation database (CDB), for 2014, there were 3154 scientific journals indexed, divided into 56 categories. For both citation databases (CDB), for 2014, the total number of categories was 232 .

A certain number of journals is found within two or more similar categories within a citation database (CDB) or within the both citation databases (CDB). Figure 3 graphically shows the number of scientific journals indexed in the SCI$\mathrm{E}$ and SSCI citation databases (CDB) and different journals in SCI-E+SSCI for 2014. For the year 2014 within the SCI-E indexed is 8659 journals, within SSCI 
indexed is 3154 journals and within SCI-E and SSCI indexed is 11200 different journals. This means that 613 journals, for 2014, are found within the SCI-E and SSCI citation databases (CDB).

Figure 3 Graphical Presentation of the Number of Journals (NoJ) Indexed in the SCI-E and SSCI and Different Journals in SCI-E+SSCI for 2014

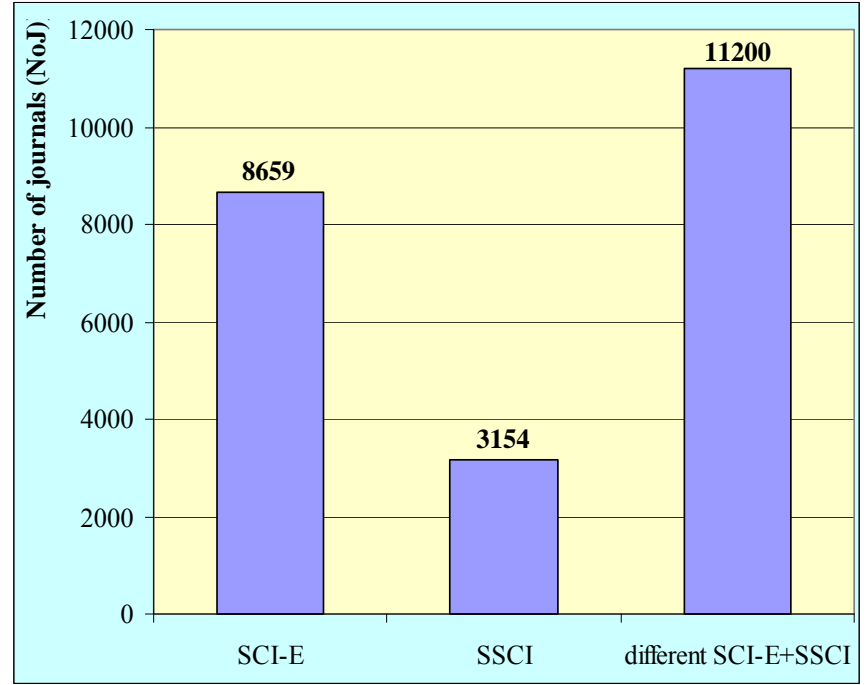

Some of the journals found within SCI-E and SSCI are, for example, the following journals: Journal of Information Technology (found in the category: "Computer Science, Information Systems", found within the SCI-E and the following categories: "Information Science \& Library Science" and "Management" found within SSCI), Journal of Operations Management (found in the category: "Operations Research \& Management Science", which is found within the SCI-E and in the category: "Management", found within SSCI), MIS (Management Information Systems) Quarterly (found in this category: "Computer Science, Information Systems", found within the SCI-E and in the following categories: "Information Science \& Library Science" and "Management" found within SSCI), Omega: International Journal of Management Science (found in the category: "Operations Research \& Management Science", which is found within the SCI-E and in the category: "Management", found within SSCI), Technovation (found in these categories: "Engineering, Industrial" and "Operations Research \& Management Science" found within the SCI-E and in the category: "Management", found within SSCI), Transportation Research. Part B: Methodological (found in the following categories: "Engineering, Civil", "Operations Research \& Management Science" and "Transportation Science \& Technology" found within the SCI-E and the categories: "Economics" and "Transportation" found within SSCI), Transportation Science (found in the 
categories: "Operations Research \& Management Science" and "Transportation Science \& Technology" found within the SCI-E and the category: "Transportation" found within SSCI) and etc.

Also, a large number of journals in the field of "Mathematical Sciences" and "Information science", found within the SCI-E publish articles in the field of "Economic Sciences", such as: time series analysis, time series models and modeling, the application of statistical methods and optimization methods in different research in the field of "Economic Sciences", the application of information and communication technologies (ICT) and software systems and tools in the field of "Economic Sciences" and etc. Thus, for example, the journal: Mathematical Problems in Engineering, found in the categories "Engineering, Multidisciplinary" and "Mathematics, Interdisciplinary Applications" found within the SCI-E in 2015 published a special issue dedicated to the time series analysis titled: Advances in Time Series Analysis and its Applications.

The fact that can be stated is that within the SCI-E and SSCI citation databases $(\mathrm{CDB})$ the categories are intertwined. Thus, for example the category "Public, Environmental \& Occupational Health" is found within the SCI-E with 165 journals and within SSCI with 147 journals in 2014 or with 250 different journals within both citation databases (CDB). Or, for example, the category "Operations Research \& Management Science" which can be classified into the scientific field belonging to the "Economic sciences" is found within the SCI-E citation database (CDB). The category "Transportation" was located until 1999 within the SCI-E and from the 1980s to the present is within SSCI citation database (CDB), so that this category until 1999 was at the same time present both in the SCI-E and SSCI. A similar category "Transportation Science \& Technology" established in 2000 is found within the SCI-E citation database (CDB). Even the categories: "Business", "Economics", "Management" and "Planning \& Development" until 1997, with a small number of journals were also present in the SCI-E citation database (CDB). Thus, for example, within the SCI-E for 1997 the category "Business" had 1 journal, "Economics" 8 journals and "Management" 9 journals.

Based on the above it is completely illogical decision of individual universities and colleges in the Republic of Serbia that the papers of authors from the Social Sciences and Humanities (društveno-humanističkih nauka - DH field) published in journals indexed in the SCI-E are not considered for selection for scientific and educational titles.

Most of the citation and bibliographical database in the world (SCI-E and SSCI, Scopus and etc.) share indexed scientific journals from certain fields, depending on the value of JIF in four quartiles (Table 2). In the first quartile Q1 classified are scientific journals that have the highest JIF values, and in the fourth quartile Q4 are classified scientific journals that have the lowest JIF values. 
Table 2 The Division of Scientific Journals into Four Quartiles Depending on the JIF Value

\begin{tabular}{|c|l|c|}
\hline QiC & \multicolumn{1}{|c|}{ Name and explanation of quartile } & Percentage [\%] \\
\hline Q1 & Top international journal in the first quartile & $0-25$ \\
\hline Q2 & International journal in the second quartile & $25-50$ \\
\hline Q3 & International journal in the third quartile & $50-75$ \\
\hline Q4 & International journal in the fourth quartile & $75-100$ \\
\hline
\end{tabular}

Ministry of Education, Science and Technological Development of Republic of Serbia (MoESTD) / Ministarstvo prosvete, nauke i tehnološkog razvoja Republike Srbije (MPNTR) in its "Regulations on the procedure and method of evaluation and quantitative expression of scientific research results of researchers" / "Pravilnik o postupku i načinu vrednovanja i kvantitativnom iskazivanju naučno-istraživačkih rezultata istraživača" (Off. Gazette of RS / Sl. glasnik RS, No. 38/2008) (within the coefficient M, of the group of results M20: Papers published in scientific journals of international importance) indexed international journals in certain fields, from the SCI-E and SSCI list, divides, depending on the JIF value, in three categories plus one category for journals of international significance verified by special decisions of MPNTR (Table 3).

Table 3 The Division of International Scientific Journals into Four Categories Depending on the JIF Value, within the Coefficient M according to MPNTR

\begin{tabular}{|c|l|c|c|c|c|}
\hline Category & Name and explanation of category & Percentage & \multicolumn{3}{|c|}{ Value of result } \\
\cline { 4 - 6 } & & {$[\%]$} & 1 & 2 & 3 \\
\hline M21 & Top international journal & $0-30$ & 8 & 8 & 8 \\
\hline M22 & Prominent international journal & $30-50$ & 5 & 5 & 5 \\
\hline M23 & International journals & $50-100$ & 3 & 3 & 4 \\
\hline M24 & $\begin{array}{l}\text { Journal of international significance } \\
\text { verified by special decision }\end{array}$ & - & 3 & 3 & 4 \\
\hline
\end{tabular}

Note: Sciences are classified as follows: 1) natural-mathematical and medical

2) technical-technological and biotechnical and 3) social and humanistic.

Information from the SCI-E and SSCI citation databases (CDB) are published in the annual publications of the company of Thomson Reuters Corp.:

- Journal Citation Report (JCR) for the printed editions and on CD-ROM and DVD (annual publications are available on the Web page: http://thomsonreuters.com/journal-citation-reports/) and

- Web of Science (WoS), for on-line publications on the Internet and on-line service (available on the Web page: http://thomsonreuters.com/thomsonreuters-web-of-science/). 
The first edition of JCR in print form was published in 1964, for information about scientific journals from 1963. JCR edition on CD-ROM are available from 1980, while the release of the DVD has been available since 2004. WoS on-line edition has been available on the Internet since 2005.

The company of Thomson Reuters Corp. also publishes several subsets of SCI-E and SSCI citation databases (CDB), entitled "Specialty Citation Indexes" (Bartol, Hocevar, 2005), such as: Neuroscience Citation Index (NCI) (Chang et al., 2011; Ward, 2014), Chemistry Citation Index (CCI) (DeWitt et al., 1980; Garfield, 1985), Materials Science Citation Index (MSCI) and etc. In the world there are a multitude of different citation databases (CDB), such as:

- Scopus (EU) (available on the Web site: http://www.scopus.com/(Abriz et al., 2013; Adriaanse, Rensleigh, 2013; Archambault et al., 2009; Bakkalbasi et al., 2006; Bar-Ilan, 2008b; Bartol et al., 2014; Berezkina, Sikorskaya, 2008; Bergman, 2012 ; Betancourt et al., 2013; Bornmann et al., 2011; Burnham, 2006; Chou, 2012; Dašić, 2015; Dašić, P. 2015b; De Groote, Raszewski, 2012; Etxebarria, Gomez Uranga, 2010; and Falagas al., 2008; Gavel, Iselid, 2008; Gupta, Dhawan, 2009; Guz, Rushchitsky, 2009a and 2009b; JACS, 2010b; Kulkarni, 2009; Lopez-Illescas et al., 2008; Marcus, 2008; Meho, Yang, 2007 Nagaraja, Vasanthakumar, 2011; Pisliakov, 2009; Torres-Salinas et al., 2009; Vieira, Gomes, 2009; Zibar Soloshenko, 2011)

- GS (Google Scholar) (available on the Web site: http://scholar.google.com/) (Adriaanse, Rensleigh, 2013; Bakkalbasi et al. 2006; Bar-Ilan, 2008b; Etxebarria, Gomez Uranga, 2010; Falagas et al., 2008; Harzing, Van der Wal, 2009; Hodge, Lacasse, 2011; JACS, 2010b, 2012a, and 2012c; Kulkarni, 2009; Levine-Clark and Kraus, 2007; Mayr, Walter, 2007; Meho, Yang, 2007; Mikki, 2010; Mingers, Lipitakis, 2010; Moskovkin, 2009; Moussa, Touzani, 2010; Murphy, Law, 2008; NORUZ, 2005; Vine, 2006)

- ProQuest-CSA (Cambridge Scientific Abstracts ProQuest) (USA) (available on the Web site: http://www.proquest.com/) (Rogers, 2007),

- CAS (Chemical Abstracts Service) (available on the Web site: https://www.cas.org/) (Levine-Clark, Kraus, 2007; Toth, 1998; Zibareva, Soloshenko, 2011),

- IEEE-Xplore or IEEE-Xplore-DL (Institute of Electrical and Electronics Engineers Explore Digital Library) (USA) (available on the Web page: http://ieeexplore.ieee.org/) (Lynn, 2010),

- ACM-DL (Association for Computing Machinery Digital Library) (USA) (available on the Web page: http://dl.acm.org/) (Chen, Fox, 2014),

- БД-ВИНИТИ-РАН or VINITI-RAS-DB (Russia) (База данных Всероссийского института научной и технической информации Российской академии наук / All-Russian Institute for Scientific and Technical Information of the Russian Academy of Sciences of DataBase) (available on 
the Web page: http://www2.viniti.ru/(Borisova, Syuntyurenko, 2007; Buil et al., 2008; Losev et al., 2009; Morozova, 2008; Shamaev, 2007)

- IC (Index-Copernicus) (Poland) (available on the Web site: http://en.indexcopernicus.com/) (Barczyński, Rek, 2011),

- CSSCI (Chinese Social Sciences Citation Index) (available on the Web page: http://cssci.nju.edu.cn/) (Su at al., 2001; Zhiren, 2002),

- DOAJ (Directory of Open Access Journals ) (available on the Web site: https://doaj.org/) (Maravić, 2005),

- SCIndeks (Serbian Citation Index) (Serbia) (available on the Web page: http://scindeks.ceon.rs/) (Šipka, 2005) and etc.

Assessment and evaluation of scientific journals in the framework of SCI-E, SSCI and A\&HCI citation databases (CDB) is determined based on the Journal Impact Factor (JIF) or shorter Impact Factor (IF), which is suggested by Eugene Garfield, since 1955 (Garfield, 1955). In the papers (Althouse et al., 2009; Egghe, 1988; Garfield, 1970; Garfield, 1972; Garfield, 2006; Garfield, Sher, 1963; Garfield, Welljams-Dorof, 1992) an analysis of JIF is given and in the papers (Fu, Ho, 2015; Ho, 2012, 2013, 2014) the top-cited articles in various scientific fields are given.

JIF is a numerical value which is determined as the average number of citations a journal realizes, in citation databases (CDB) of the company of Thomson Reuters Corp.: SCI-E, SSCI and A\&HCI, during the current year for the papers published in the last two years. On the basis of the JIF impact factor of journals is determined, based on which the score is determined, and thus also categorization is performed and the rank and quality of the journal are determined. It is determined and published for each year, in late June of next year, by the company of Thomson Reuters Corp. within the JCR publication and WoS on-line service:

Information on the Journal Impact Factor for different fields of science are available on the Web page: http://thomsonreuters.com/products_services/ science/science_products/a-z/journal_citation_reports/.

Later on, several different varieties of bibliographic indicators were defined to measure the performance of journals, articles, scientific and educational institutions and authors, such as:

- IFwoJSC (Impact Factor without Journal Self Cites), included and calculated for all journals indexed in SCI-E and SSCI citation databases (CDB);

- IFwJSC (Impact Factor only with Journal Self Cites);

- 5YIF or IF-5 (Five-Year Impact Factor or Five-Year Impact Factor Journal Including Self-Citations) (Jacsó, 2009), which is included and calculated, starting from 2007, for all journals indexed in SCI-E and SSCI citation databases $(\mathrm{CDB})$; 
- \%ACI (\% Articles in Citable Items), included and calculated for all journals indexed in SCI-E and SSCI citation databases (CDB);

- II (Immediacy Index) (Asai, 1981; Dašić, Karić, 2015c; Huang, Lin, 2012; Luciano, 2012; Magri, Solari, 1996; Ortner, 2010; Tomer, 1986; Yue et al., 2004), which is included and calculated for all journals indexed in SCI-E and SSCI citation databases (CDB);

- CHL (Cited Half Life) (Della Sala, Crawford, 2007; Dašić, Karić, 2015c; Magri et al., 1996), which is included and calculated for all journals indexed in SCI-E and SSCI citation databases (CDB);

- CngHL (Citing Half Life) (Dašić, Karić, 2015c), which is included and calculated for all journals indexed in SCI-E and SSCI citation databases (CDB);

- EF (Eigenfactor) or ES (Eigenfactor Score), proposed by Carl T. Bergstrom in 2007 (Bergstrom, 2007), Carl T. Bergstrom, Jevin D. West and Marc A. Wiseman in 2008 (Bergstrom et al., 2008) and Jevin D. West in 2008 and 2010 (West, 2008 and 2010) and used in the papers (Dašić, Karić, 2015d; Davis, 2008; Fersht, 2009; Jacsó, 2010a and 2012b; Rizkallah, Sin, 2010; Sillet et al., 2012; Yin, 2011), which is included and calculated, starting from 2007, for all journals indexed in SCI-E and SSCI citation databases (CDB), and is available on the Web site: http://www.eigenfactor.org/;

- NEF (Normalized Eigenfactor or Normalized Eigenfactor Score), which is included and calculated, starting from 2007, for all journals indexed in SCI-E and SSCI citation databases (CDB);

- AI (Article Influence) or AS (Article Influence Score) (Arendt, 2010; Chang et al., 2011 and 2013; Dašić, Karić, 2015d; Jacsó, 2010a; Rizkallah, Sin, 2010; Walters, 2014), which is included and calculated, starting from 2007, for all journals indexed in SCI-E and SSCI citation databases (CDB);

- h-index (Hirsch Index), proposed by Jorge E. Hirsch in 2005 (Hirsch, 2007) and the characteristics of h-index were analyzed in the papers (Abbas, 2012; Alonso et al., 2009; 2008; Banks, 2006; Bar-Ilan, 2006, 2008a and 2008b; Bornmann, 2008; Burrell, 2007; Costas, Bordons, 2007; Courtault et al., 2010; De Groote, Raszewski, 2012; Dodson, 2009; Egghe, 2007 and 2008; Egghe et al., 2009; Esposito, 2010; Gągolewski, Mesiar, 2012; Glänzel, 2006; Guan, Gao, 2009; Guns, Rousseau, 2009; Harzing, Van der Wal, 2009; Hodge, Lacasse, 2011; Jacsó, 2012c; Kellner, Ponciano, 2008; Kelly, Jennions, 2007; Lacasse et al., 2011; Lazaridis, 2010; Liu, Lu, 2012; Nair, Turlach, 2012; Norris, Oppenheim, 2010; Quesada, 2009; Rousseau, 2007; Schreiber, 2010; Sidiropoulos et al., 2006; Tol, 2009; Vanclay, 2008; Van Raan, 2006; Wu et al., 2011; Zhang, 2010);

- SNIP (Source Normalized Impact per Paper), developed by Henk F. Moed in 2010 and 2011 (Moed, 2010 and 2011) and described by Loet Leydesdorff and Tobias Opthof in 2010 (Leydesdorff, Opthof, 2010), which is included and calculated, starting from 1996, for all journals indexed in Scopus citation 
database (CDB) (Elsevier B.V.), and is available on the Web site: http://www.journalmetrics.com/ and http://www.scopus.com/;

- IPP (Impact per Publication), which is included and calculated, starting from 1996, for all journals indexed in Scopus citation database (CDB) (Elsevier B.V.), and is available on the Web site: http://www.journalmetrics.com/ and http://www.scopus.com/;

- \%NC (\% Not Cited), which is included and calculated, starting from 1996, for all journals indexed in Scopus citation database (CDB) (Elsevier B.V.);

- SJR (SCImago Journal Rank), developed by SCImago Lab. (Web site: http://www.scimagolab.com/), from the widely known algorithm Google PageRank (Bollen et al., 2006) and used in the papers (Falagas, 2008), which is included and calculated, starting from 1996, for all journals indexed in Scopus (Elsevier B.V.) and SCImago citation databases (CDB), and is available on the Web site: http://www.scimagojr.com/;

- \%IC (\% International Collaboration), which is included and calculated, starting from 1996, for all journals indexed in the SCImago citation database $(\mathrm{CDB})$ and

- i10-index, which is included and calculated for all journals, indexed in Google Scholar (GS) citation database (CDB) and etc.

\section{Data and Methods}

The data used for this analysis of scientific journals in the field of "Economic Sciences" for the period 1995-2014 were taken from the Journals Citation Reports (JCR). Within the SCI-E citation database (CDB) all scientific journals are divided by scientific fields or categories. Scientific journals in the scientific field "Economic Sciences", within SSCI citation database (CDB) are classified within the following 8 categories:

- Business (Bus),

- Business, Finance (BusFin),

- Economics (Econ),

- Industrial Relations \& Labor (IR\&L),

- International Relations (IR),

- Management (Manag),

- Planning \& Development (P\&D) and

- Public Administration (PubAdm).

The category International Relations (IR) is a multidisciplinary category, but since there are a large number of journals in the field of "Economic Sciences" it has been discussed in this paper. 
Scientific journals in the scientific field "Economic Sciences" within the SCI-E citation database (CDB) appear within the category of "Operations Research \& Management Science" (OR\&MS).

In the group of scientific fields "Economic Sciences" another multidisciplinary category can be considered, namely "Agricultural Economics \& Policy" (AE\&P), with 17 journals for 2014. Due to the volume of the paper, this category is not considered.

For the analysis and graphical presentation of results, the standard methods of statistical and bibliometric analysis are used (Dašić, 2011, 2012, 2013a, 2013b and Dašić, 2015c; Dašić, Karic, 2015a and 2015a; Dašić et al., 2015; Ristović et al., 2014).

\section{Results and Discussions}

Table 4 presents the total number of scientific journals indexed in the SSCI and SCI-E citation databases (CDB) with a category rank according to the number of scientific journals, for the nine categories in the field of "Economic Sciences" for the period 1995-2014, and in Figure 4 it is graphically presented.

In the last column in Table 4 the total number of different journals is given indexed in the SSCI and SCI-E for the nine categories in the field of "Economic Sciences" for the period 1995-2014. Data for the total number of different journals indexed in the SSCI and SCI-E for the period 1995-1996 were not available.

In Table 4 the data for the number of journals are not shown from the following categories: "Business", "Economics", "Management" and "Planning \& Development" found within the SCI-E for the period 1995-1997 because the category rank in JCR is determined only on the basis of a number of journals in the SSCI citation database (CDB).

For the following nine categories in the field of "Economic Sciences" for 2014 the largest number of scientific journals by far had the category of "Economics" (Econ) with 333 journals (ranked at 1/56 within SSCI), followed by the categories: "Management" (Manag) with 185 journals (ranked at 3/56 within SSCI), "Business" (Bus) with 115 journals (ranked at 12/56 within SSCI), "Business Finance" (BusFin) with 88 journals (ranked at 16/56 within SSCI), "International Relations" (IR) with 85 journals (ranked at 18/56 within SSCI), "Operations Research \& Management Science" (OR\&MS) with 81 journal (ranked at 58/176 within SCI-E), "Planning \& Development" (P\&D) with 55 journals (ranked at 30/56 within SSCI), "Public Administration" (PubAdm) with 46 journals (ranked at 34/56) and "Industrial Relations \& Labor" (IR\&L) with 27 journals (ranked at 50/56 within SSCI) (Table 4 and Figure 4). 
Table 4 Table of the Total Number of Scientific Journals Indexed in the SSCI and SCI-E, as Well as Their Ranking for the Nine Listed Categories in the Field of “Economic Sciences” for the Period 1995-2014

\begin{tabular}{|c|c|c|c|c|c|c|c|c|c|c|c|c|c|c|c|c|c|c|c|}
\hline \multirow[t]{2}{*}{ Year } & \multicolumn{2}{|c|}{ Bus } & \multicolumn{2}{|c|}{ BusFin } & \multicolumn{2}{|c|}{ Econ } & \multicolumn{2}{|c|}{ IR\&L } & \multicolumn{2}{|c|}{ IR } & \multicolumn{2}{|c|}{ Manag } & \multicolumn{2}{|c|}{\begin{tabular}{l|l} 
OR\&MS \\
\end{tabular}} & \multicolumn{2}{|c|}{ P\&D } & \multicolumn{2}{|c|}{ PubAdm } & \multirow{2}{*}{$\begin{array}{l}\text { Total } \\
\text { Value }\end{array}$} \\
\hline & Value & Rank & Value & Rank & Value & Rank & Value & Rank & Value & Rank & Value & Rank & Value & Rank & Value & Rank & Value & Rank & \\
\hline 995 & 46 & $11 / 64$ & 33 & $19 / 64$ & 142 & $1 / 64$ & 20 & $32 / 64$ & 46 & $11 / 64$ & 38 & $15 / 64$ & 34 & $78 / 183$ & \begin{tabular}{|l|l|}
31 \\
\end{tabular} & & 18 & $35 / 64$ & \\
\hline 1996 & & 59 & & $/ 59$ & & $1 / 59$ & & $3 / 59$ & 47 & $12 / 59$ & & $11 / 59$ & 3 & & & $1 / 59$ & & $1 / 59$ & - \\
\hline & & & & & & & & & & $15 / 57$ & & $10 / 5$ & & & & & 24 & & 415 \\
\hline & & & & $1 / 56$ & 161 & $1 / 56$ & & 156 & & $13 / 56$ & & $10 / 56$ & 4 & $77 / 1$ & & & & & 13 \\
\hline & & & & $28 / 55$ & & $1 / 55$ & & 5 & & $13 / 55$ & & $10 / 55$ & 50 & & 39 & & 24 & $3 / 55$ & 26 \\
\hline & & & & $29 / 55$ & 166 & $1 / 55$ & & $47 / 55$ & & $15 / 55$ & & $10 / 55$ & 5 & $66 / 169$ & & 55 & 24 & $3 / 55$ & 29 \\
\hline & & & & 54 & & $1 / 54$ & & 4 & & $15 / 54$ & & $10 / 54$ & & & & & 4 & & 29 \\
\hline & & & & $29 / 54$ & 166 & $1 / 54$ & 17. & $45 / 54$ & & $15 / 54$ & & $10 / 54$ & 54 & & 7 & $4 / 54$ & 24 & $8 / 54$ & 36 \\
\hline & & & & 26 & & $1 / 54$ & & $6 / 5$ & & $16 / 54$ & & 9/54 & & $60 / 1$ & & $3 / 54$ & 4 & $1 / 54$ & 49 \\
\hline & 5 & & & 27 & & $1 / 54$ & & & 5 & $14 / 54$ & 6 & $10 / 54$ & 5 & & & & & & 53 \\
\hline & 61 & & & $24 / 54$ & 175 & $1 / 54$ & & $46 / 54$ & & $18 / 54$ & & $9 / 54$ & 56 & $66 / 1$ & & & 5 & & 57 \\
\hline 06 & 6 & & & $24 / 55$ & & $1 / 55$ & & $49 / 5$ & & $19 / 55$ & & $8 / 55$ & & $60 / 1$ & & 55 & & $2 / 55$ & 167 \\
\hline & & & & & & & & & & $20 / 55$ & & & & & & & & & 96 \\
\hline 08 & 77 & & & 25 & & $1 / 56$ & & $5 / 3$ & & $21 / 56$ & & $7 / 56$ & 6 & & & 56 & 28 & $1 / 56$ & 32 \\
\hline 09 & 87 & & 5 & & & $1 / 55$ & & & & $21 / 55$ & & $5 / 55$ & 73 & & & $1 / 55$ & 32 & $/ 55$ & 15 \\
\hline & & & & & & & & & & $16 / 56$ & & & & & & & & & 50 \\
\hline & 11 & & & & & $1 / 56$ & & $50 /$ & & $19 / 56$ & & $3 / 5$ & 77 & & & & 45 & 4/56 & 815 \\
\hline 012 & 116 & $11 / 56$ & 8 & $16 / 5$ & 333 & $1 / 56$ & & $51 / 5$ & & $18 / 56$ & 17 & $3 / 56$ & 79 & & 5 & $30 / 56$ & 47 & 4/56 & 40 \\
\hline & 11 & & 9 & & 333 & $1 / 56$ & 26 & & & $18 / 56$ & 17 & $3 / 5$ & 75 & & & & 0 & 4/56 & 41 \\
\hline 014 & 115 & $12 / 56$ & 88 & $16 / 56$ & 333 & $1 / 56$ & 27 & $50 / 56$ & 85 & $18 / 56$ & 185 & $3 / 56$ & 81 & $58 / 176$ & 55 & $30 / 56$ & 46 & $34 / 56$ & 860 \\
\hline
\end{tabular}

There was a similar order by the categories for the nine listed categories in the field of "Economic Sciences", according to the number of scientific journals for the entire period 1995-2014 (Table 4 and Figure 4). Top ranked category from the listed nine in the field of "Economic Sciences" was the category of "Economics" (Econ), which according to the number of journals for the entire period 1995-2014, was always ranked as the first (top one) within the SSCI. Then follow the categories: "Management" (Manag), "Business" (Bus) and etc. (Table 4).

Figure 4 Graphical Presentation of the Total Number of Scientific Journals Indexed in the SSCI and SCI- E for the Nine Listed Categories in the Field of "Economic Sciences" for the Period 1995-2014

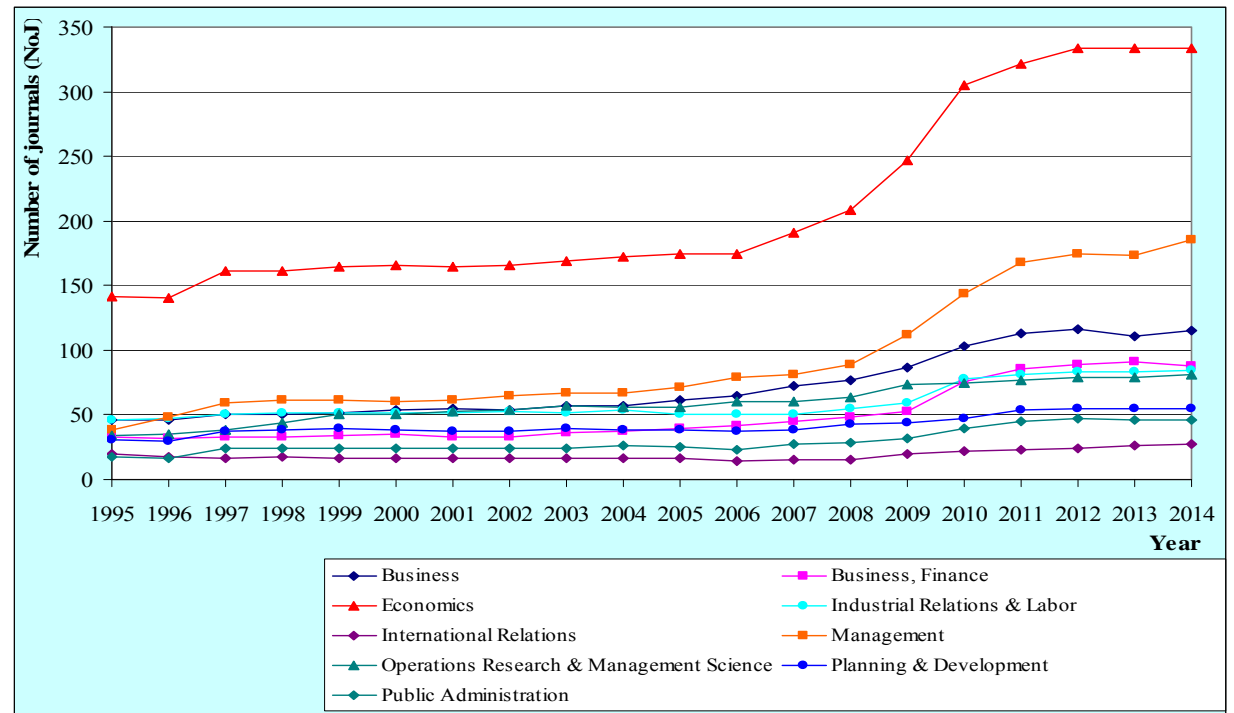


The total number of different scientific journals indexed in SCIE and SCI-E for the nine listed categories in the field of "Economic Sciences" and their annual growth in [\%] for the period 1995-2014 is shown in Figure 5. The number of different scientific journals indexed in the SSCI and SCI-E for the nine categories in the field of "Economic Sciences" for the period 1997-2014, increased for 445 journals (from 415 journals in 1997 to 860 journals in 2014), with cumulative growth index (CGI) of $207,23 \%$ in regard to 1997 and had a generally still increasing trend of growth of scientific journals, with the exception of 1998.

Figure 5 Graphical Presentation of the Total Number of Different Scientific Journals Indexed in the SSCI and SCI-E and Their Annual Growth in [\%] for the Nine Listed Categories in the Field of "Economic Sciences" for the Period 1997-2014

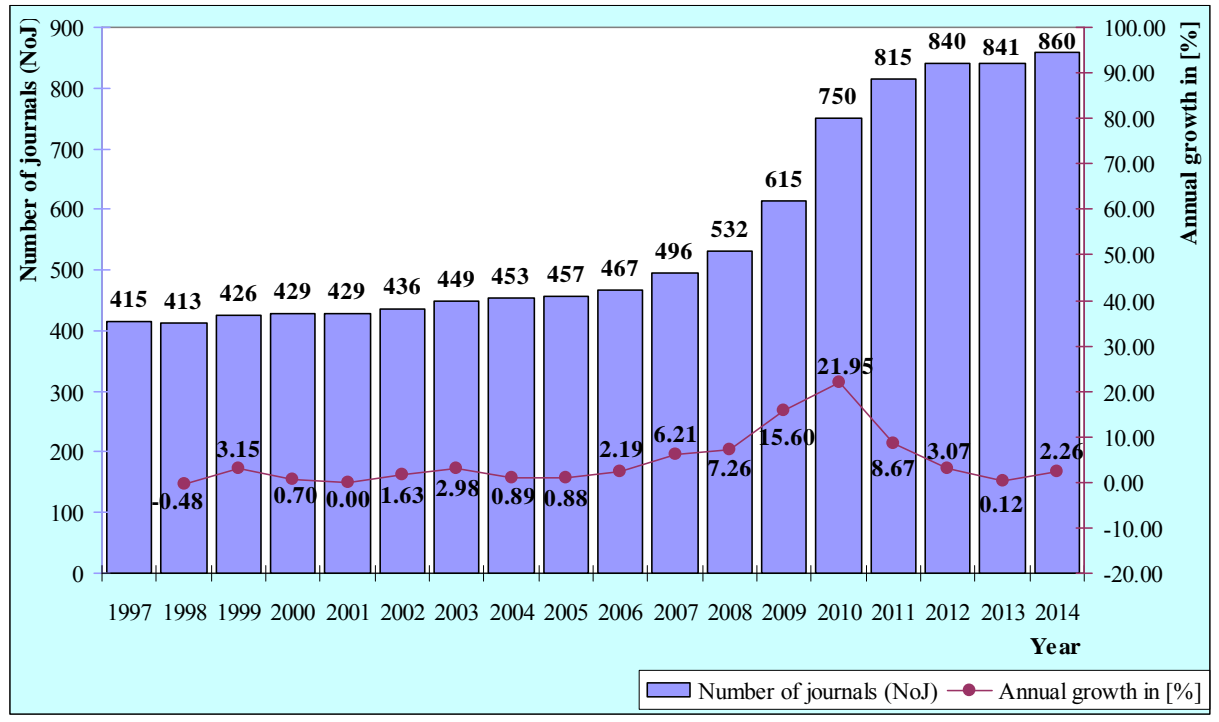

The highest annual growth in the number of various scientific journals of the nine listed categories in the field of "Economic Sciences" was in 2010 for 135 journals (from 615 journals in 2009 to 750 journals in 2010) or for $21,95 \%$, and then in 2009 for 83 journals or for $15,60 \%$ and 2011 for 65 journals or for $8,67 \%$. The only annual decrease in the number of various scientific journals for the nine listed categories in the field of "Economic Sciences" was in 1998 for 2 journals or for $0,48 \%$.

From the total number of different scientific journals indexed in SSCI and SCI-E for the nine listed categories in the field of "Economic Sciences", top-five journals with the highest number of Total Citations (TC) in 2014 are the journals: American Economic Review (found in the category: "Economics" found within SSCI) with 33621 TC; European Journal of Operational Research (found in the 
category: "Operations Research \& Management Science" found within SCI-E) with 29872 TC; Journal of Applied Psychology (found in the categories: "Management" and "Psychology, Applied" found within SSCI) with 25194 TC; Econometrica (found in the categories: "Mathematics, Interdisciplinary Applications" and "Statistics \& Probability" found within SCI-E and in the categories: "Economics" and "Social Sciences, Mathematical Methods" found within SSCI) with 24175 TC and Journal of Finance (found within the categories: "Business, Finance" and "Economics" found within SSCI) with 23535 TC.

From the total number of different scientific journals indexed in SSCI and SCI-E for the nine listed categories in the field of "Economic Sciences", top-five journals with the highest value of Journal Impact Factor (JIF) in 2014 are the journals: Academy of Management Annals (found in the category: "Management" found within SSCI) with $\mathrm{JIF}_{2014}=7,769$; Academy of Management Review (found in the following categories: "Business" and "Management" found within SSCI) with $\mathrm{JIF}_{2014}=7,475$; Quarterly Journal of Economics (found in the category: "Management" found within SSCI) with $\mathrm{JIF}_{2014}=6,654$; Academy of Management Review (found in the following categories: "Business" and "Management" found within SSCI) with $\mathrm{JIF}_{2014}=6,448$; and Journal of Management (found in the categories: "Business", "Management" and "Psychology, Applied" found within SSCI) with $\mathrm{JIF}_{2014}=6,071$.

From the total number of different scientific journals indexed in SSCI and SCI-E for the nine categories in the field of "Economic Sciences", top-five journals with the highest value of Five-Year Impact Factor (5Y-IF) in 2014 are the journals: Journal of Economic Literature (found in the category: "Economics" found within SSCI) with $5 \mathrm{Y}-\mathrm{IF}_{2014}=11,762$; Academy of Management Annals (found in the following category: "Management" found within SSCI) with 5Y-IF $\mathrm{IF}_{2014}=10,866$; Academy of Management Review (found in the following categories: "Business" and "Management" found within SSCI) with 5Y- $\mathrm{IF}_{2014}=10,736$; and Academy of Management Journal (found in the categories: "Business" and "Management" found within SSCI) with 5Y$\mathrm{IF}_{2014}=9,812$; Quarterly Journal of Economics (found in the category: "Economics", which is found within SSCI) with $5 \mathrm{Y}-\mathrm{IF}_{2014}=9,794$.

From the total number of different scientific journals indexed in SSCI and SCI-E for the nine categories in the field of "Economic Sciences", top-five journals with the highest value of Immediacy Index (II) in 2014 are the journals: Asian Economic Policy Review (found in the category: "Economics" found within SSCI) with $\mathrm{II}_{2014}=5,231$; Management and Organization Review (found in the following category: "Management", found within SSCI) with $\mathrm{II}_{2014}=1,714$; Oxford Review of Economic Policy (found in the category: "Economics", found within SSCI) with $\mathrm{II}_{2014}=1,667$; Environment and Planning. C: Government and Policy (found in the categories: "Environmental Studies" and "Public Administration" found within $\mathrm{SSCI}$ ) with $\mathrm{II}_{2014}=1,542$ and the American 
Economic Journal: Economic Policy (found in the category: "Economics", found within SSCI) with $\mathrm{II}_{2014}=1,432$.

The total number of scientific journals indexed in SCIE and SCI-E citation databases (CDB), and their annual growth in [\%] for the nine categories in the field of "Economic Sciences" for the period 1995-2014 is shown in Figure 6.

Figure 6 Graphical Presentation the Total Number of Scientific Journals Indexed in the SSCI and SCI-E Citation Databases (CDB) and Their Annual Growth in [\%] for the Nine Categories in the Field of "Economic Sciences” for the Period 1995-2014

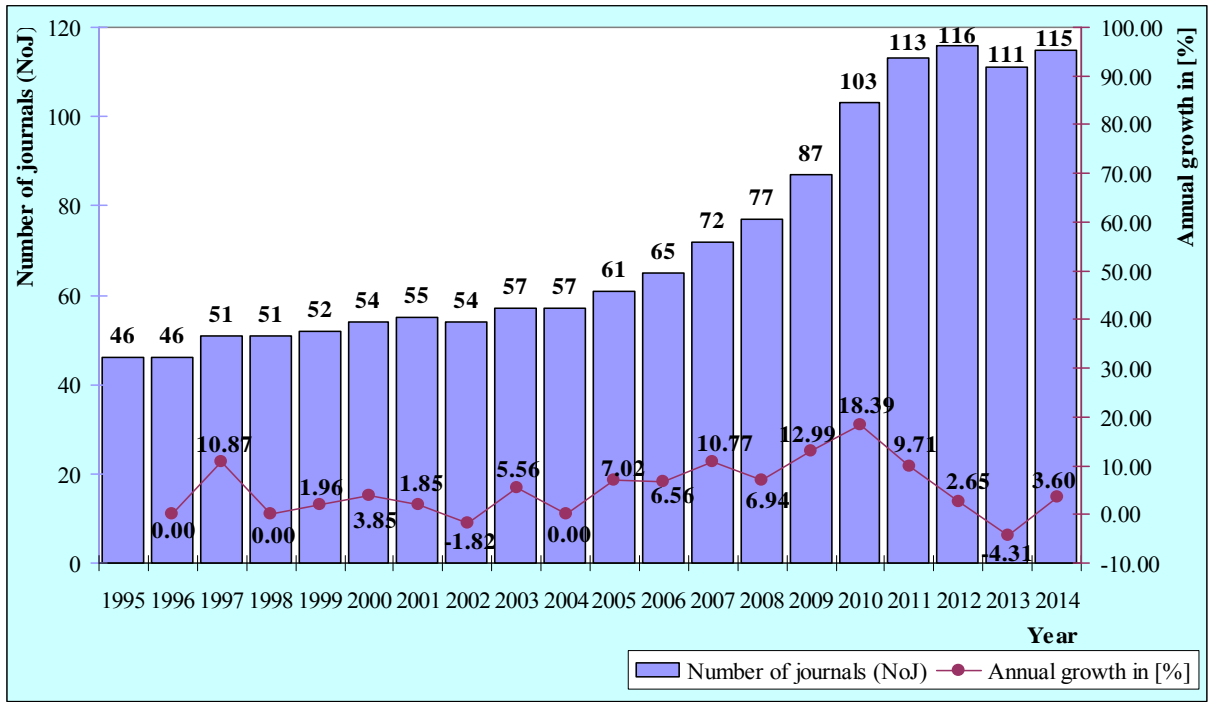

a) for the category: "Business" (Bus)

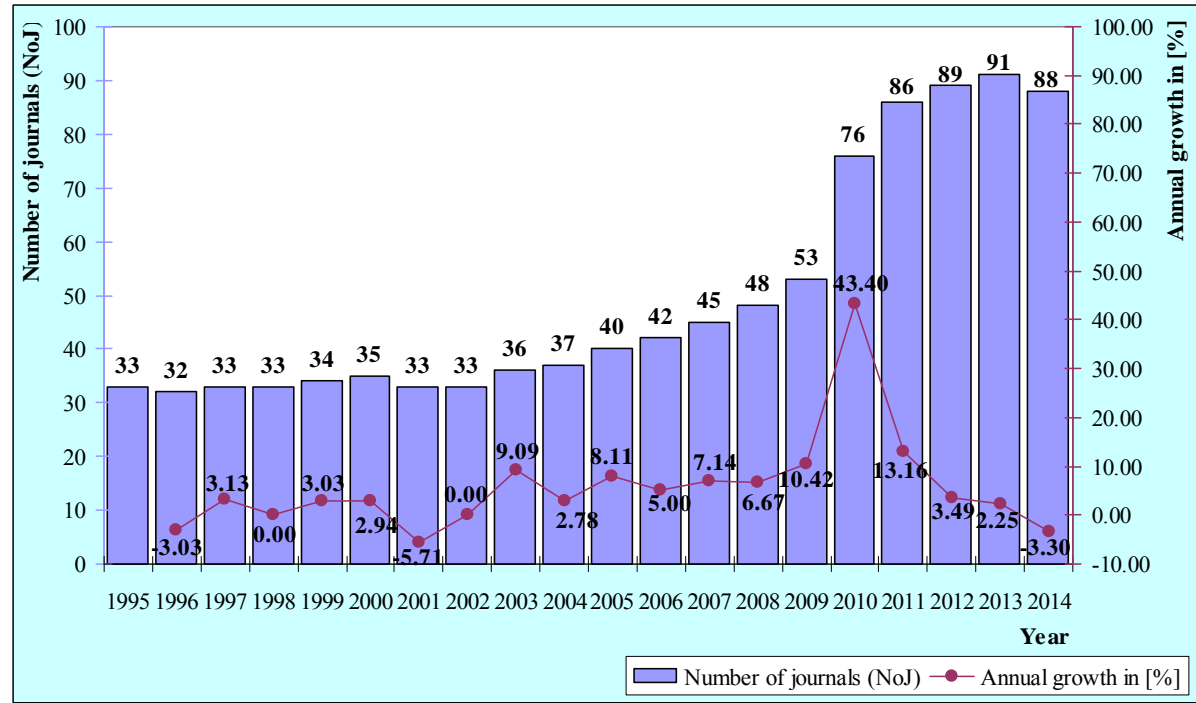

b) for the category: "Business, Finance" (BusFin) 


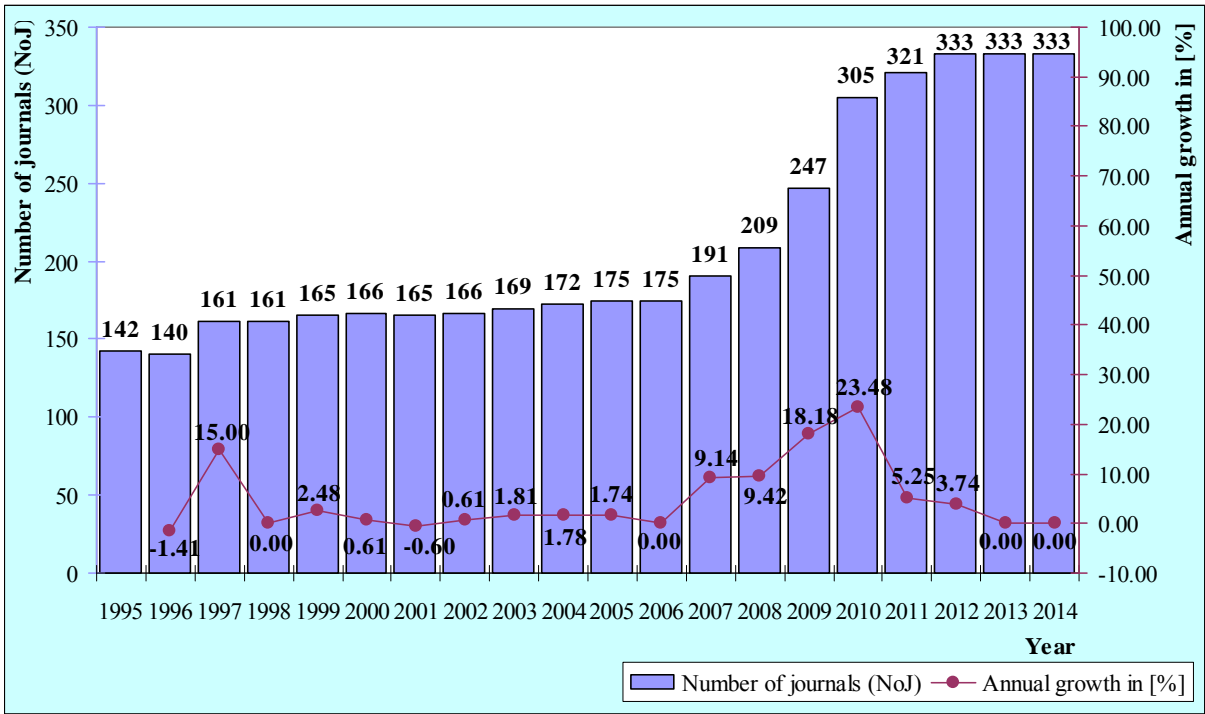

c) for the category: "Economics" (Econ)

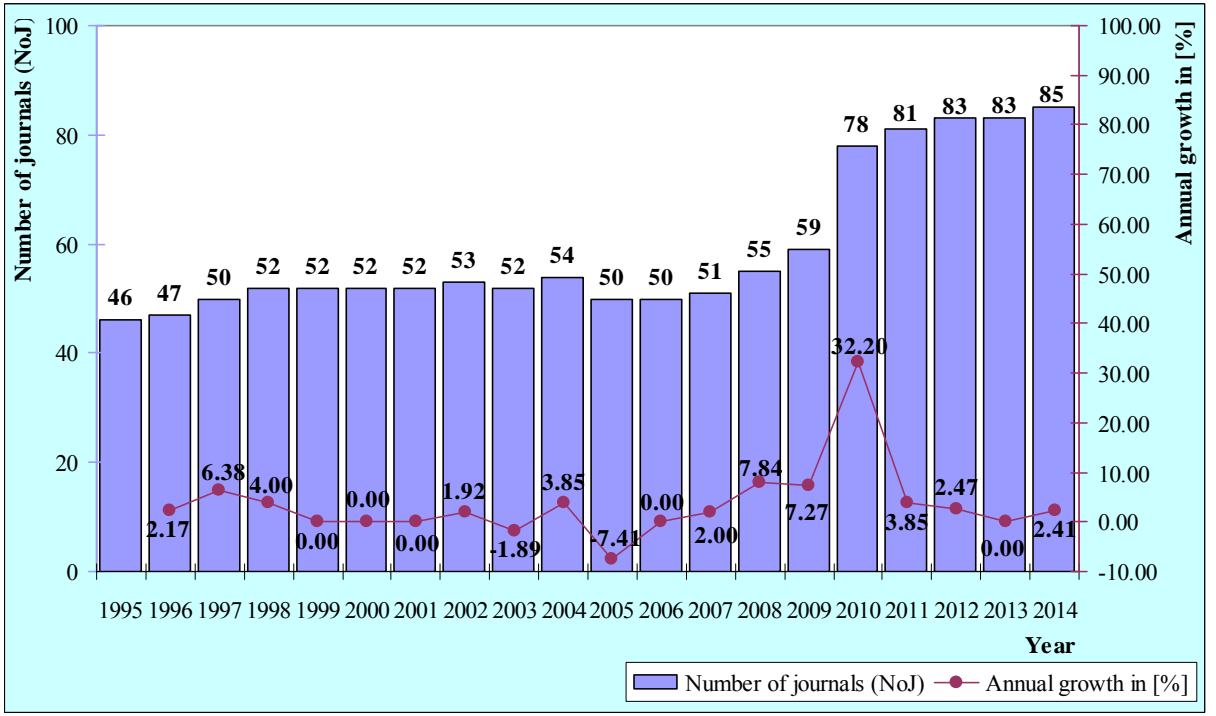

d) for the category: "Industrial Relations \& Labor" (IR\&L) 


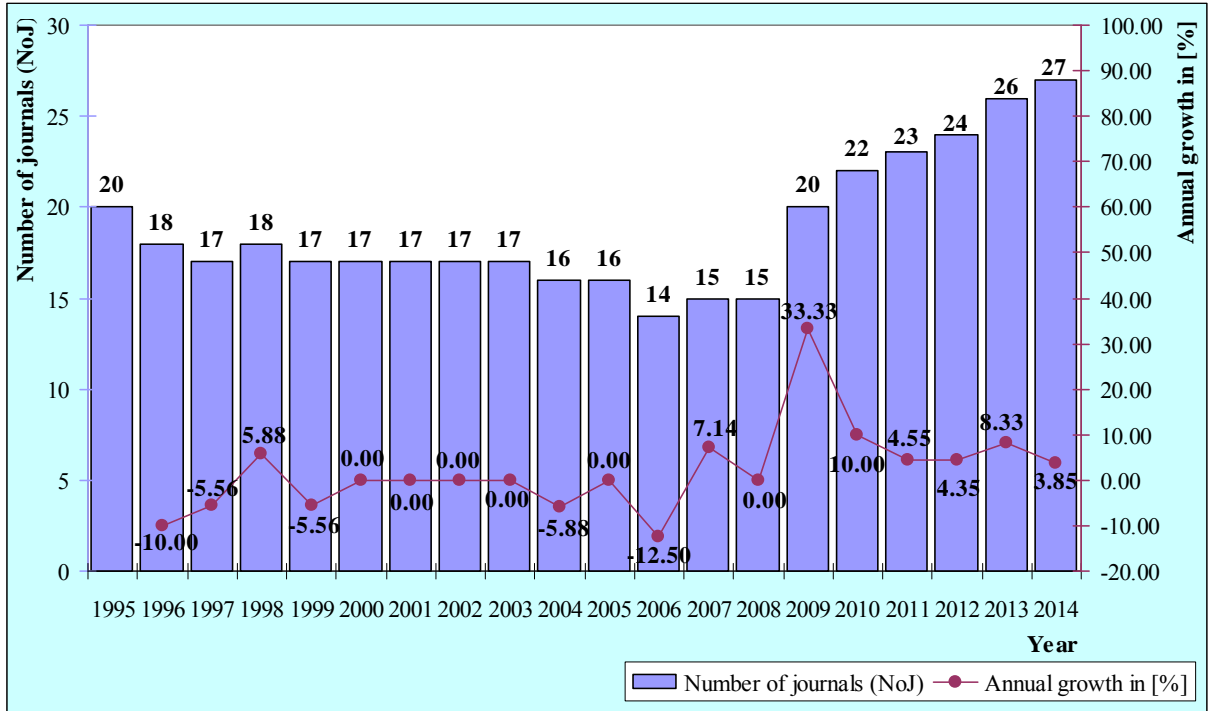

e) for the category: "International Relations" (IR)

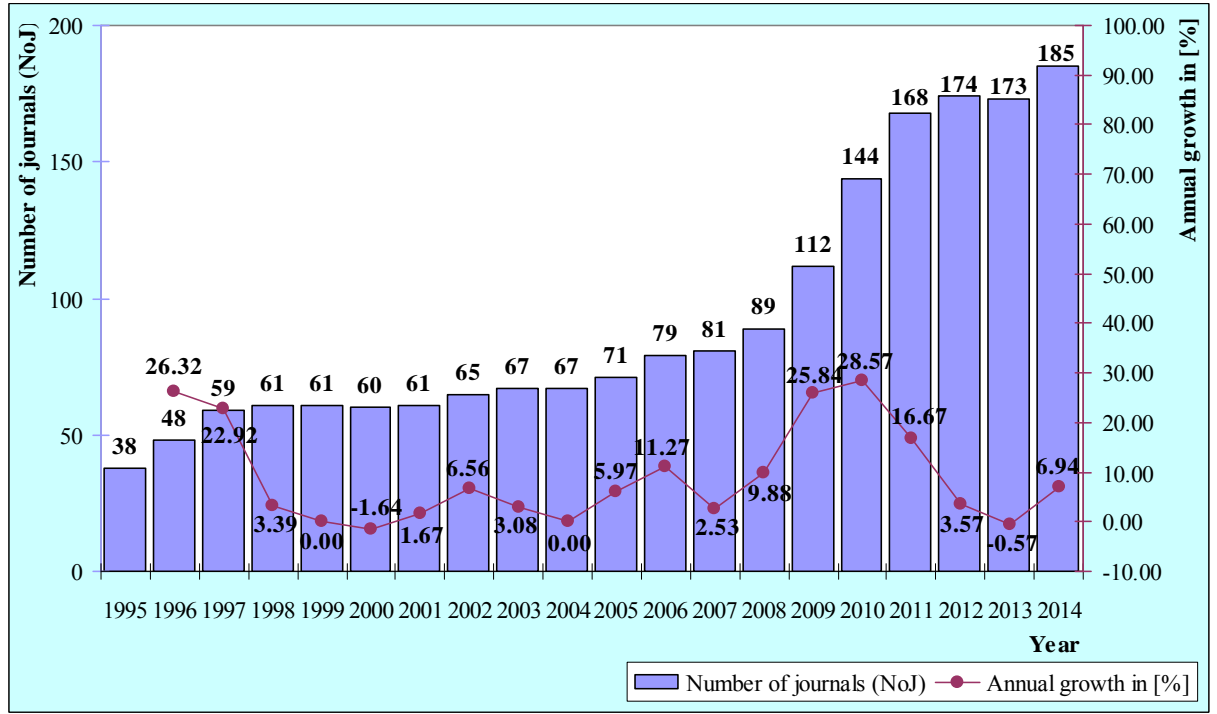

f) for the category: "Management" (Manag) 


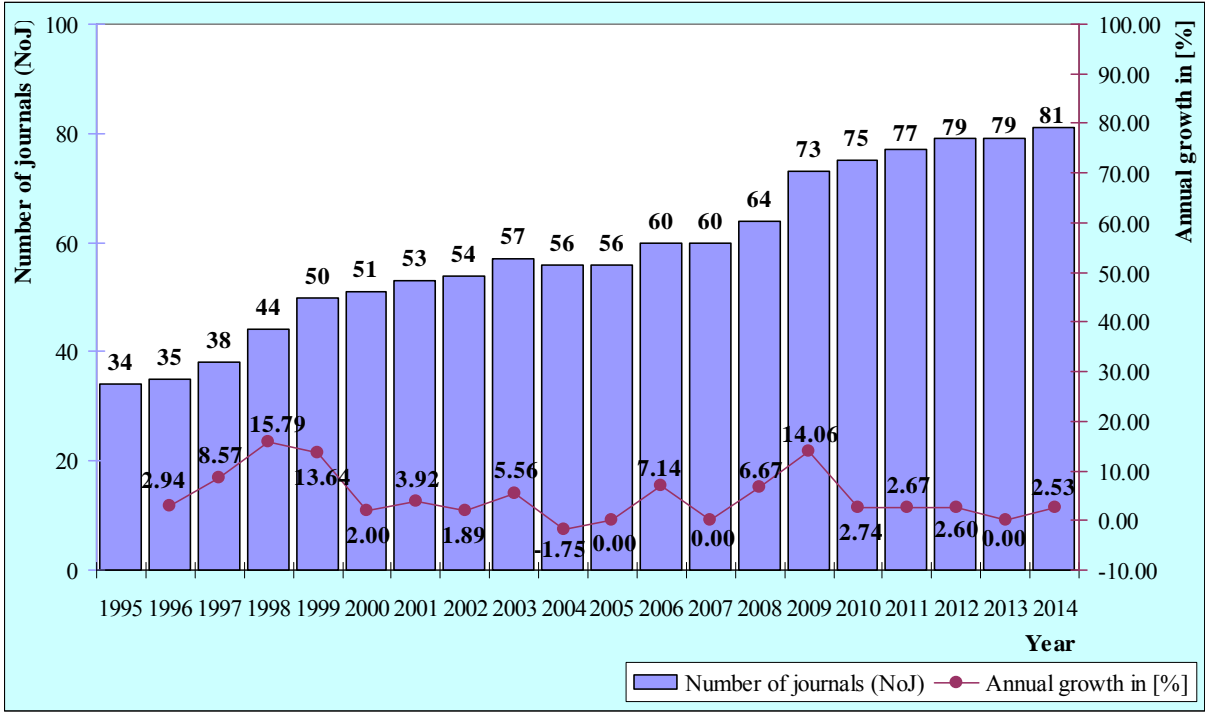

g) for the category: "Operations Research \& Management Science” (OR\&MS)

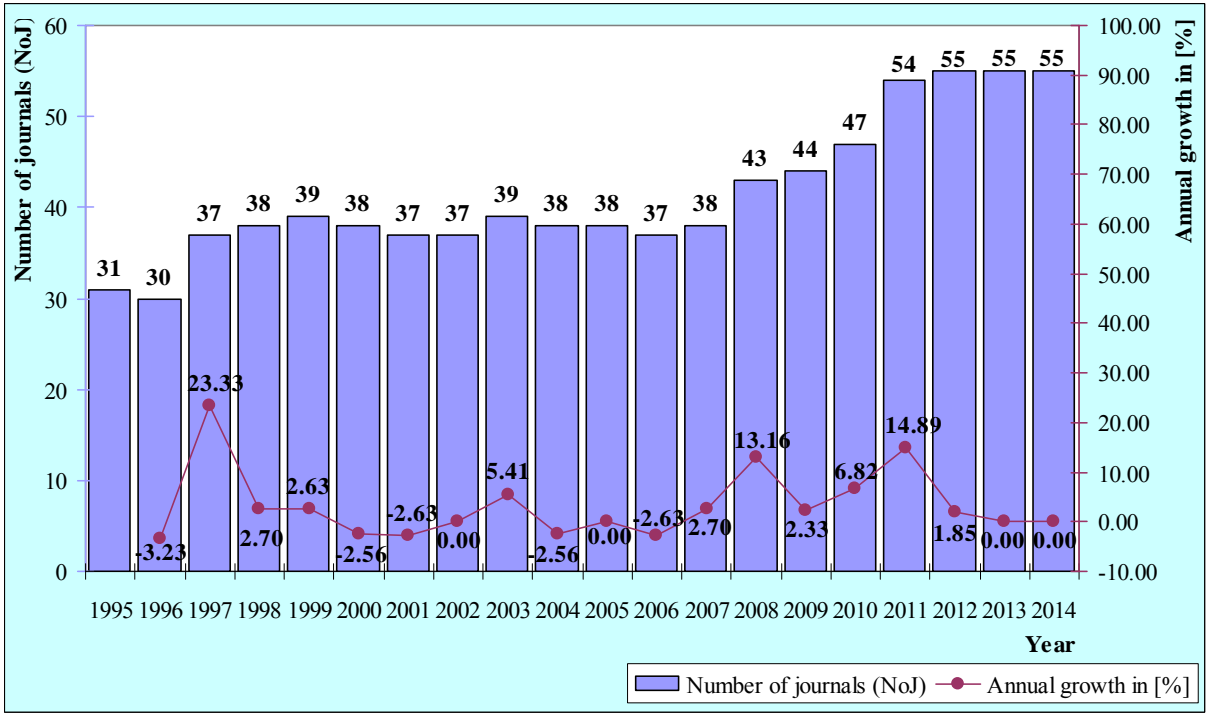

h) for the category: "Planning \& Development" (P\&D) 


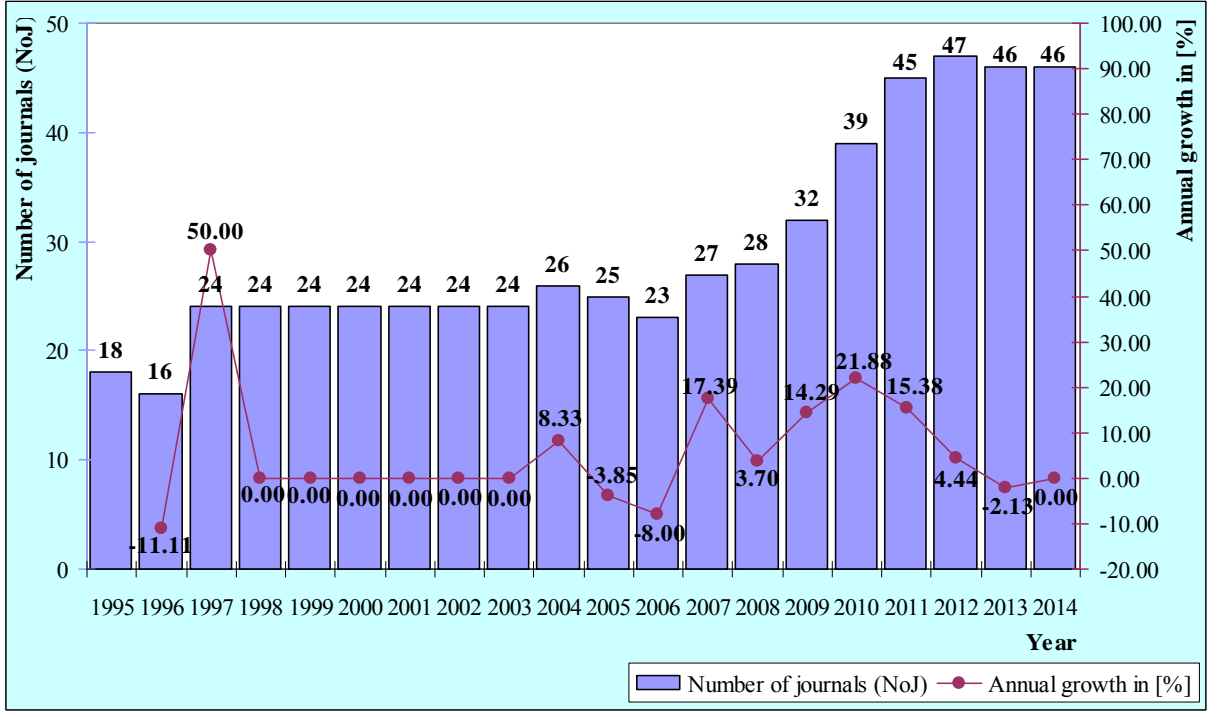

i) for the category: "Public Administration" (PubAdm)

For the category "Business" (Bus) the number of scientific journals, for the period 1995-2014, has increased for 69 journals (from 46 journals in 1995 to 115 journals in 2014), with cumulative growth index (CGI) of $250 \%$ in regard to 1995 and had a generally upward trend of growth in the number of scientific journals, with the exception in 2002 and 2013 (Figure 6a). The largest annual increase in the number of journals in the category "Business" was in 2010 for 16 journals (from 87 journals in 2009 to 103 journals in 2010) or for $18,39 \%$, followed by 2009 and 2011 for 10 journals or for $12,99 \%$ in 2009 and for $9,71 \%$ in 2011, retrospectively and etc. (Figure 6a). The highest annual decrease in the number of journals in the category "Business" was in 2013 for 5 journals (from 116 journals in 2012 to 111 journals in 2013) or for 4,31\% (Figure 6a). In that year, for certain reasons (due to: a large number of self-citations of the journal, the increased number of articles, ceased publication and etc.) from SSCI citation database (CDB) the following journals have got out: Asian Case Research Journal (found in the category: "Business" found within SSCI), INNOVAR: Revista de Ciencias Administrativas y Sociales (found in the categories: "Business", "Management" and "Public Administration" found within SSCI), International Entrepreneurship and Management Journal (IEMJ) (found in the categories: "Business" and "Management" found within SSCI) (indexed for the first time in 2012, removed from the list in 2013 and re-indexed in 2014), Management Decision (found in the categories: "Business" and "Management" found within SSCI) (which is indexed for the first time in 1981, and then from 2009-2012, removed from the list in 2013 and re-indexed in 2014), Revista de Ciencias Sociales (found in categories: "Business" and "Economics" found 
within SSCI) and Universia Business Review (found in the category: "Business", found within SSCI), and re-indexed is the journal: Journal of Consumer Psychology (found in the categories: "Business" and "Psychology, Applied" found within SSCI) (which is indexed for the first time in 2002 in the category of "Psychology, Applied", inserted also in 2007 in the category "Business", taken off the list from 2011-2012 and re-indexed from 2013-2014). In this category for the period 1995-2014 the annual reduction of journals was even in 2002 for 1 journal or for $1,82 \%$.

For the category of "Business, Finance" (BusFin) the number of scientific journals, for the period 1995-2014, increased for 55 journals (from 33 journals in 1995 to 88 journals in 2014), with cumulative growth index (CGI) of 266,67 \% with regard to 1995 and had a generally upward trend in the number of scientific journals, with the exception of 1996, 2001 and 2014 (Figure 6b). The largest annual increase in the number of journals in the category "Business Finance" was in 2010 for 23 journals (from 53 journals in 2009 to 76 journals in 2010 ) or for $43,40 \%$, followed by 2011 for 10 journals or for $13,16 \%$ (Figure $6 \mathrm{~b})$. The highest annual decrease in the number of journals in the category "Business, Finance" was in 2014 for 3 journals (from 91 journals in 2013 to 88 journals in 2014) or for 3,30\% (Figure 6b). In that year, 2014, for certain reasons (due to: a large number of self-citations of the journal, the increased number of articles, ceased publication and etc.) from SSCI citation database (CDB) the following journals have been withdrawn: Iktisat Isletme ve Finans (found in the category: "Business, Finance" and "Economics" found within SSCI), Journal of Real Estate Research (JRER) (found in these categories: "Business, Finance" and "Economics" found within SSCI), North American Journal of Economics and Finance (found in these categories: "Business, Finance" and "Economics" found within SSCI) and National Tax Journal (NTJ) (found in these categories: "Business, Finance" and "Economics" found within $\mathrm{SSCI}$ ), and for the first time indexed is the journal: International Journal of Accounting Information Systems (IJAIS) (found in the categories: "Business", "Business, Finance" and "Management" found within SSCI). In this category for the period 1995-2014 the annual reduction of journals was even in 2001 for 2 journals or for $5,71 \%$ and in 1996 for 1 journal or for 3,03\%.

For the category of "Economics" (Econ) the number of scientific journals, for the period 1995-2014, increased for 191 journals (from 142 journals in 1995 to 333 journals in 2014), with cumulative growth index (CGI) of $234,51 \%$ in regard to 1995 and had a generally upward trend in the number of scientific journals, with the exception of 1996 and 2001 (Figure 6c). The largest annual increase in the number of journals in the category of "Economics" was in 2010 for 58 journals (from 247 journals in 2009 to 305 journals in 2010) or for $23,48 \%$, and then in 2009 for 38 journals or for $18,18 \%$, followed by 1997 for 21 journals or for $15,00 \%$ (Figure $6 \mathrm{c}$ ). The only annual reduction of the number 
of journals in the category of "Economics" was in 1996 for 2 journals or for $1,41 \%$ and in 2001 for 1 journal or for $0,60 \%$ (Figure $6 \mathrm{c}$ ).

For the category of "Industrial Relations \& Labor" (IR\&L) the number of scientific journals, for the period 1995-2014, increased only for 7 journals (from 20 journals in 1995 to 27 journals in 2014), with cumulative growth index (CGI) of $135,00 \%$ with regard to 1995 and had a trend of fluctuation of the number of scientific journals (Figure 6d). It is the category that had the lowest annual increase in the number of journals. The largest annual increase in the number of journals in the category "Industrial Relations \& Labor" was in 2009 for 5 journals (from 15 journals in 2008 to 20 journals in 2009) or for $33,33 \%$ and etc. (Figure 6d). In the period from 2010-2014 this category had a slight increase in the number of scientific journals. In the previous period from 1995-2006 this category had a mostly trend of a slight decrease in the number of scientific journals (Figure 6d).

For the category of "International Relations" (IR) the number of scientific journals, for the period 1995-2014, increased for 39 journals (from 46 journals in 1995 to 85 journals in 2014), with cumulative growth index (CGI) of $184,78 \%$ in regard to 1995 and had a generally upward trend in the number of scientific journals, with the exception of 2003 and 2005 (Figure 6e). The largest annual increase in the number of journals in the category "International Relations" was in 2010 for 19 journals (from 59 journals in 2009 to 78 journals in 2010) or for $32,20 \%$ and etc. (Figure 6e). In other years during the aforementioned period, this category had a slight increase in the number of scientific journals. The only annual reduction of journals in the category "International Relations" was in 2005 for 4 journals or for 7,41\% and in 2003 for 1 journal or for 1,89\% (Figure 6e).

For the category of "Management" (Manag) the number of scientific journals, for the period 1995-2014, increased for 147 journals (from 38 journals in 1995 to 185 journals and 2014), with cumulative growth index (CGI) of 486,84\% with regard to 1995 and had a generally upward trend in the number of scientific journals, with the exception of 2000 and 2013 (Figure 6f). It is the category that had the highest annual increase in the number of journals. The largest annual increase in the number of journals in the category "Management" was in 2010 for 32 journals (from 112 journals in 2009 to 144 journals in 2010) or for $28,57 \%$, followed by 2011 for 24 journals or for $16,67 \%$, followed by 2009 for 23 journals or for $25,84 \%$ and etc. (Figure $6 \mathrm{f}$ ). The only annual reduction of journals in the category "Management" was in 2000 and 2013 for 1 journal or for 1,64\% in 2000 and for $0,57 \%$ in 2013 (Figure 6f).

For the category "Operations Research \& Management Science" (OR\&MS) the number of scientific journals, for the period 1995-2014, increased for 47 journals (from 34 journals in 1995 to 81 journal in 2014), with cumulative growth index (CGI) of $238,24 \%$ compared to 1995 and had a generally upward trend in the number of scientific journals, with the exception of 2004 (Figure 6g). The 
largest annual increase in the number of journals in the category of "Operations Research \& Management Science" was in 2009 for 9 journals (from 64 journals in 2008 to 73 journals in 2009) or for 14,06\%, followed by 1998 and 1999 for 6 journals or for $15,79 \%$ and for $13,64 \%$, respectively (Figure $6 \mathrm{~g}$ ). In other years during the aforementioned period, this category had a slight increase in the number of scientific journals. The only annual reduction of the number of journals in the category of "Operations Research \& Management Science" was in 2004 for 1 journal or for $1,75 \%$ (Figure $6 \mathrm{~g}$ ).

For the category "Planning \& Development" (P\&D) the number of scientific journals, for the period 1995-2014, increased for 24 journals (from 31 journals in 1995 to 55 journals in 2014), with cumulative growth index (CGI) of 177,42\% in regard to 1995 and had a generally upward trend in the number of scientific journals, with the exception of 1996, 2000, 2001, 2004 and 2006 (Figure 6h). The largest annual increase in the number of journals in the category of "Planning \& Development" was in 1997 and 2011 for 7 journals or for 23,33\% and for $14,89 \%$, respectively (Figure 6h). In 1997, a number of journals from this category which was also within the SCI-E moved into this category within SSCI. In other years during the aforementioned period, this category had a slight increase in the number of scientific journals. The annual decrease in the number of journals in the category of "Planning \& Development" was in 1996, 2000, 2001, 2004 and 2006 for 1 journal (Figure 6h).

The category "Public Administration" (PubAdm) the number of scientific journals, for the period 1995-2014, increased for 28 journals (from 18 journals in 1995 to 46 journals in 2014), with cumulative growth index (CGI) of $255,56 \%$ compared to 1995 and had a generally upward trend in the number of scientific journals, with the exception of 1996, 2005, 2006 and 2013 (Figure 6i). The largest annual increase in the number of journals in the category "Public Administration" was in 1997 for 8 journals (from 16 journals in 1996 to 24 journals in 1997) or for $50,00 \%$, followed by 2010 for 7 journals or for $21,88 \%$, as well as in 2011 for 6 journals or for $15,38 \%$ (Figure 6i). The annual reduction in the number of journals in the category "Public Administration" was in 1996 and 2006 for 2 journals or for $11,11 \%$ in 1996 and for $8,00 \%$ in 2006 (Figure 6i).

\section{Conclusion}

For the year 2014 within the SCI-E was indexed 8659 journals, divided into 176 categories, and within SSCI was indexed 3154 journals, divided into 56 categories. Within the SCI and SSCI was indexed 11200 different journals, which means that 613 journals are within both citation databases (CDB).

Certain categories of the same scientific field can be found in the SCI-E and/or SSCI. Thus, for example, the category "Operations Research \& 
Management Science" (OR\&MS) that belongs to the field of "Economic Sciences" is found within the SCI-E.

Based on the above analysis of categories within SCI-E and SSCI the question of non-recognition of papers is raised published in journals indexed in the SCI-E, by the authors from the Social Sciences and Humanities (DH field), for the selection of scientific and educational titles at different universities and faculties in the Republic of Serbia.

Generally, the highest annual growth of scientific journals for all the nine listed categories in the field of "Economic Sciences" for the specified period 1995-2014, was in 2009 and 2010. The largest increase in the number of scientific journals for the period 1995-2014 for all the nine listed categories in the field of "Economic Sciences" had the category of "Management" (Manag) for 147 journals (from 38 journals in 1995 to 185 journals in 2014) with cumulative growth index (CGI) of $486,84 \%$ compared to 1995 . The lowest increase had the category "Industrial Relations \& Labor" (IR\& L) for only 7 journals (from 20 journals in 1995 to 27 journals in 2014) with cumulative growth index (CGI) of 135,00\% compared to 1995 .

Top ranked category from the nine in the field of "Economic Sciences" was the category "Economics" (Econ), followed by the categories: "Management" (Manag), "Business" (Bus) and etc. The category "Economics" (Econ), according to the number of journals for the entire period 1995-2014, was ranked as the first (top one) within the SSCI citation database (CDB) (Table 4). The category "Economics" (Econ), according to the number of journals in the period 20102014, she was ranked as the first (top one) within both SSCI and SCI-E citation databases (CDB), while in the period 1995-2009 it ranked from 3rd to 7th place.

\section{References}

Abbas, A.M. (2012) "Bounds and inequalities relating h-index, g-index, e-index and generalized impact factor: An improvement over existing models", PLoS (Public Library of Science) One, 7 (4): 1-7.

Abrizah, A., A.N. Zainab, K. Kiran and R.G. Raj (2013) "LIS journals scientific impact and subject categorization: A comparison between Web of Science and Scopus", Scientometrics, 94 (2): 721-740.

Adriaanse, L.S. and C. Rensleigh (2013) "Web of Science, Scopus and Google Scholar: A content comprehensiveness comparison", The Electronic Library, 31 (6): 727-744.

Alonso, S., F.J. Cabrerizo, E. Herrera-Viedma and F. Herrera (2009) "h-index: A review focused in its variants, computation and standardization for different scientific fields", Journal of Informetrics, 3 (4): 273-289.

Althouse, B.M., J.D. West, C.T. Bergstrom and T. Bergstrom (2009) "Differences in impact factor across fields and over time", Journal of the American Society for Information Science and Technology (JASIST), 60 (1): 27-34. 
Andreis, M. and M. Jokić (2008) "An impact of Croatian journals measured by citation analysis from SCI-expanded database in time span 1975-2001", Scientometrics, 75 (2): 263-288.

Archambault, É., D. Campbell, Y. Gingras and V. Larivière (2009) "Comparing bibliometric statistics obtained from the Web of Science and Scopus", Journal of the American Society for Information Science and Technology, 60 (7): 1320-1326.

Arendt, J. (2010) "Are article influence scores comparable across scientific fields?" Issues in Science and Technology Librarianship, 60.

Asai, I (1981) "Adjusted age distribution and its application to impact factor and immediacy index", Journal of the American Society for Information Science (JASIS), 32 (3): 172-174.

Bakkalbasi, N., K. Bauer, J. Glover and L. Wang (2006) "Three options for citation tracking: Google Scholar, Scopus and Web of Science", Biomedical Digital Libraries, 3 (1): Article 7: pp. 1-8.

Banks, M.G. (2006) "An extension of the Hirsch index: Indexing scientific topics and compounds", Scientometrics, 69 (1): 161-168.

Barczyński, B.J. and M. Rek (2011) "Evaluation in science - Index Copernicus case study of multi-parametric evaluation system", Archives of Budo, 7 (2): 93-103.

Bar-Ilan, J. (2008a) "The h-index of h-index and of other informetric topics", Scientometrics, 75 (3): 591-605.

Bar-Ilan, J. (2008b) "Which h-index? - A comparison of WoS, Scopus and Google Scholar", Scientometrics, 74 (2): 257-271.

Bar-Ilan, J. (2010) "Rankings of information and library science journals by JIF and by htype indices", Journal of Informetrics, 4 (2): 141-147.

Bartol, T., G. Budimir, D. Dekleva-Smrekar, M. Pusnik and P. Juznic (2014) “Assessment of research fields in Scopus and Web of Science in the view of national research evaluation in Slovenia”, Scientometrics, 98 (2): 1491-1504.

Berezkina, N.Yu. and O.N. Sikorskaya (2008) "Assessment of the research activities of Russian and Belarussian scientists (according to Scopus data)", Scientific and Technical Information Processing, 35 (6): 256-259.

Bergman, E.M.L. (2012) "Finding citations to social work literature: The relative benefits of using Web of Science, Scopus, or Google Scholar", The Journal of Academic Librarianship, 38 (6): 370-379.

Bergstrom C.T. (2007) "Eigenfactor: Measuring the value and prestige of scholarly journals ", College \& Research Libraries News, 68 (5): 314-316.

Bergstrom, C.T. West, J.D. and M.A. Wiseman (2008) "The Eigenfactor metrics", The Journal of Neuroscience, 28 (45): 11433-11434.

Betancourt, K.G., M.R. de Zayas Pérez and M.V. González Guitián (2013) “Análisis bibliométrico de las publicaciones relacionadas con proyectos de innovación y su gestión en Scopus, en el período 2001-2011", Revista Cubana de Información en Ciencias de la Salud, 24 (3): 281-294.

Bollen, J., M.A. Rodriquez and H. Van de Sompel, (2006) "Journal status", Scientometrics, 69 (3): 669-687.

Borisova, L.F. and O.V. Syuntyurenko (2007) "VINITI RAN abstract database: Prospects of information postprocessing using methods of data analysis", Scientific and Technical Information Processing, 34 (6): 278-283.

Bornmann, L. (2008) “The h-index and its variants: Which works best?", Research Trends, (5): 5-6. 
Bornmann, L., L. Leydesdorff, C. Walch-Solimena and C. Ettl (2011) "Mapping excellence in the geography of science: An approach based on Scopus data", Journal of Informetrics, 5 (4): 537-546.

Buchanan, R.A. (2007) "Science Citation Index Expanded: The effect of journal editorial policies", The Journal of Academic Librarianship, 33 (5): 532-539.

Builova, N.M. Osipov, A.I. and E.M. Epshtein (2008) "On the rubrication of the journal The Physics of Nanoobjects and Nanotechnology from the AJ Physics of the VINITI RAS", Automatic Documentation and Mathematical Linguistics, 42 (6): 269-271.

Burnham, J.F. (2006) "Scopus database: A review", Biomedical Digital Libraries, 3: Article 1: pp. 1-8.

Burrell, Q.L. (2007) "Hirsch's h-index: A stochastic model”, Journal of Informetrics, 1(1): 16-25.

Caplin A. and A. Schotter (2008) "The foundations of positive and normative economics", Oxford University Press, pp. 416.

Chang, C.-L. McAleer, M. and L. Oxley (2011) "How are journal impact, prestige and article influence related? An application to neuroscience", Journal of Applied Statistics, 38 (11): 2563-2573.

Chang, C.-L., M. McAleer and L. Oxley (2013) "Corecive journal self citations, impact factor, Journal Influence and Article Influence", Mathematics and Computers in Simulation, 93: 190-197.

Chen, Y. and E.A. Fox (2014) "Using ACM DL paper metadata as an auxiliary source for building educational collections", In: Proceedings of the ACM/IEEE Joint Conference on Digital Libraries, London: IEEE, pp. 137-140.

Chou, P.-N. (2012) "Database comparison between Web of Science and Scopus: A case of educational technology journals ", International Journal of Information and Education Technology (IJIET), 2 (6): 584-586.

Costas, R. and M. Bordons (2007) "The h-index: Advantages, limitations and its relation with other bibliometric indicators at the micro level", Journal of Informetrics, 1 (3): 193-203.

Courtault, J.-M. Hayek, N. Rimbaux, E. and T. Zhu (2010) "Research in economics and management in France: A bibliometric study using the h-index", The Journal of Socio-Economics, 39 (2): 329-337.

Dašić, P. (2011) "Analysis of the journal impact factor in field of economics and management", In: Proceedings of the 1st International Conference Economics and Management-Based on New Technologies (EMoNT-2011), Vrnjačka Banja: SaTCIP Publisher Ltd., pp. 33-42.

Dašić, P. (2012) “Application of polynomial regression models for approximation of time series", Journal of Economic and Management Based on New Technologies, 1 (2) 81-160.

Dašić, P. (2013a) "State of the art of reference journals indexed by SCI and SCI-E for 2008-2012", Journal of Research and Development in Mechanical Industry, 5 (3): pp. 181-260.

Dašić, P. (2013b) "State of the art of reference journals indexed by SSCI for 2008-2012", Journal of Economic and Management Based on New Technologies, 2 (3): 121-200.

Dašić, P. (2015a) "A comprehensive analysis of bibliometric indicators for category "Management" within SSCI based on JCR and Scopus data", Journal of Economic and Management Based on New Technologies, 4 (3). 
Dašić, P. (2015b) "A comprehensive analysis of bibliometric indicators for category "Mechanical Engineering" within SCI-E based on JCR and Scopus data", Journal of Research and Development in Mechanical Industry, 7 (3).

Dašić, P. (2015c). "State and analysis of scientific journals in the field of "Mechanical sciences" within SCI-E for the period 1985-2014", Journal of Research and Development in Mechanical Industry, 7 (2): 35-50.

Dašić, P. and M. Karić (2015a) "A comprehensive bibliometric analysis for category "Thermodynamics" within SCI-E. Part 1: Trend analysis of number of journals, articles and total citations"; Journal of Research and Development in Mechanical Industry, 7 (2).

Dašić, P. and M. Karić (2015b) "A comprehensive bibliometric analysis for category "Thermodynamics" within SCI-E. Part 2: Analysis of scientific journals by countries and continents", Journal of Research and Development in Mechanical Industry, 7 (2).

Dašić, P. and M. Karić (2016a) "A comprehensive bibliometric analysis for category "Thermodynamics" within SCI-E. Part 5: Analysis of II, CHL and CngHL", Applied Mechanics and Materials, 830: 249-257.

Dašić, P. and M. Karić (2016b) "A comprehensive bibliometric analysis for category "Thermodynamics" within SCI-E. Part 6: Analysis of EF and AI", Applied Mechanics and Materials, 830: 258-270.

Dašić, P. Moldovan, L. and L. Grama (2015) "Status and analysis of scientific journals indexed in SCI, SCI-E and SSCI citation databases from Romania and Serbia", Procedia Technology, 19: 1075-1082.

Davis, P. M. (2008) "Eigenfactor: Does the principle of repeated improvement result in better estimates than raw citation counts?", Journal of the American Society for Information Science and Technology (JASIST), 59 (13) 2186-2188.

De Groote, S. L. and R. Raszewski (2012) "Coverage of Google Scholar, Scopus and Web of Science: A case study of the h-index in nursing", Nursing Outlook, 60 (6): 391400.

Della, S.S. and J. R. Crawford (2007) "A double dissociation between impact factor and cited half life", Cortex, 43 (2) 174-175.

Dewitt, T. W., R. S. Nicholson, and M. K. Wilson (1980) "Science Citation Index and Chemistry", Scientometrics, 2(4): 265-75.

Dodson, M.V. (2009) "Citation analysis: Maintenance of h-index and use of e-index", Biochemical and Biophysical Research Communications, 387 (4): 625-626.

Egghe, L. (1988) "Mathematical relations between impact factors and average number of citations", Information Processing \& Management, 24 (5) 567-576.

Egghe, L. (2007) "Dynamic h-index: The Hirsch index in function of time", Journal of the American Society for Information Science and Technology (JASIST), 58 (3): $452-$ 454.

Egghe, L. (2008) "Examples of simple transformations of the h-index: Qualitative and quantitative conclusions and consequences for other indices", Journal of Informetrics, 2 (2): 136-148.

Egghe, L. Liang, L. and R. Rousseau (2009) "A relation between h-index and impact factor in the power-law model", Journal of the American Society for Information Science and Technology (JASIST), 60 (11): 2362-2365.

Esposito, M. (2010) "H-index: An index to quantifiy the impact of scientific research", European Journal of Oral Implantology, 3 (1): 3-4. 
Etxebarria, G. and M. Gomez-Uranga (2010) "Use of Scopus and Google Scholar to measure social sciences production in four major Spanish universities", Scientometrics, 82 (2): 333-349.

Falagas, M.E., E.I. Pitsouni, G.A. Malietzis and G. Pappas (2008) "Comparison of PubMed, Scopus, Web of Science and Google Scholar: Strengths and weaknesses", FASEB Journal, 22 (2): 338-342.

Falagas, M.E., V.D. Kouranos, R. Arencibia-Jorge and D.E. Karageorgopoulos (2008) "Comparison of SCImago journal rank indicator with journal impact factor", The FASEB Journal, 22 (8): 2623-2628.

Fersht, A. (2009) "The most influential journals : Impact Factor and Eigenfactor", Proceedings of the National Academy of Sciences of the United States of America (PNAS), 106 (17): 6883-6884.

Fu, H.-Z. and Y.-S. Ho (2013) "Independent research of China in Science Citation Index Expanded during 1980-2011", Journal of Informetrics, 7 (1): 210-222.

$\mathrm{Fu}, \mathrm{H} . \mathrm{Z}$. and Y.-S. Ho (2015) "Top cited articles in thermodynamic research", Journal of Engineering Thermophysics, 24 (1): 68-85.

Gągolewski, M. and R. Mesiar (2012) "Aggregating different paper quality measures with a generalized h-index", Journal of Informetrics, 6 (4) 566-579.

Garfield, E. (1955) "Citation indexes to science: A new dimension in documentation through association of ideas", Science, 122 (3159): 108-111.

Garfield, E. (1970) "Citation indexing for studying science", Nature, 227(5259): 669-671.

Garfield, E. (1972) "Citation analysis as a tool in journal evaluation: Journals can be ranked by frequency and impact of citations for science policy studies", Science, 178 (4060): 471-479.

Garfield, E. (1985) "History of Citation Indexes for Chemistry: A brief review", Journal of Chemical Information and Computer Sciences, 25 (3): 170-174.

Garfield, E. (2006) "The history and meaning of the journal impact factor", Journal of the American Medical Association (JAMA), 295(1): 90-93.

Garfield, E. and A. Welljams-Dorof (1992) "Of Nobel class: A citation perspective on high impact research authors", Theoretical Medicine and Bioethics, 13 (2): 117-135.

Garfield, E. and I.H. Sher (1963) "New factors in evaluation of scientific literature through citation indexing", American Documentation, 14 (3): 195-201.

Gavel, Y. and L. Iselid (2008) "Web of Science and Scopus: A journal title overlap study", Online Information Review, 32 (1): 8-21.

Glänzel, W. (2006) "On the h-index - A mathematical approach to a new measure of publication activity and citation impact", Scientometrics, 67 (2): 315-321.

Guan, J.C. and X. Gao (2009) "Exploring the h-index at patent level", Journal of the American Society for Information Science and Technology (JASIST), 60 (1): 35-40.

Guns, R. and R. Rousseau (2009) "Real and rational variants of the h-index and the gindex", Journal of Informetrics, 3(1): 64-71.

Gupta, B.M. and S.M. Dhawan (2009) "Status of India in science and technology as reflected in its publication output in the Scopus international database, 1996-2006", Scientometrics, 80 (2): 473-490.

Guz, A.N. and J.J. Rushchitsky (2009a) "On the level of coverage and citation of publications by mechanicians of the National Academy of Sciences of Ukraine in the Scopus database", International Applied Mechanics, 45 (11): 1153-1161.

Guz, A.N. and J.J. Rushchitsky (2009b) "Scopus: A system for the evaluation of scientific journals ”, International Applied Mechanics, 45 (4): 351-362. 
Harzing, A.-W. K. and R. Van der Wal (2009) "A Google Scholar h-index for journals : An alternative metric to measure journal impact in economics and business", Journal of the American Society for Information Science and Technology (JASIST), 60 (1): 41-46.

Herubel, J.-P. V. M. and A. L. Buchanan (1993) "Using SSCI to map scholarly influence in the social sciences: Braudel and annales historiography", Behavioral \& Social Sciences Librarian, 12 (1): 45-51.

Hirsch, J. E. (2007) "Does the $\mathrm{h}$ index have predictive power?", Proceedings of the National Academy of Sciences of the United States of America (PNAS), 104 (49): 19193-19198.

Ho, Y.-S. (2012) "Top-cited articles in chemical engineering in science citation index expanded: A bibliometric analysis", Chinese Journal of Chemical Engineering, 20 (3): 478-488.

Ho, Y.-S. (2013) "The top-cited research works in the Science Citation Index Expanded", Scientometrics, 94 (3): 1297-1312.

Ho, Y.S. (2014) "A bibliometric analysis of highly cited articles in materials science", Current Science, 107 (9): 1565-1572.

Hodge, D. R. and J. R. Lacasse (2011) "Ranking disciplinary journals with the Google Scholar h-index: A new tool for constructing cases for tenure, promotion, and other professional decisions", Journal of Social Work Education, 47 (3): 579-596.

Huang, A.H.-M. (2009) "Science as ideology: SSCI, TSSCI and the evaluation system of social sciences in Taiwan", Inter-Asia Cultural Studies, 10 (2): 282-291.

Huang, M.-H. and W.-Y.C. Lin (2012) "The influence of journal self-citations on journal impact factor and immediacy index”, Online Information Review, 36 (5): 639-654.

Ingwersen, P., J.W. Schneider, M. Scharff and B. Larsen (2007) "A national research profile-based immediacy index and citation ratio indicator for research evaluation", In: Proceedings of 11th International Conference of the International Society for Scientometrics and Informetrics (ISSI-2007), Madrid: Spanish National Research Council, pp. 864-865.

Jacsó, P. (2009) "Five-year impact factor data in the Journal Citation Reports", Online Information Review, 33 (3): 603-614.

Jacsó, P. (2010a) "Eigenfactor and article influence scores in the Journal Citation Reports", Online Information Review, 34 (2) 339-348.

Jacsò, P. (2010b) "Pragmatic issues in calculating and comparing the quantity and quality of research through rating and ranking of researchers based on peer reviews and bibliometric indicators from Web of Science, Scopus and Google Scholar", Online Information Review, 34 (6): 972-982.

Jacsó, P. (2012a) “Google Scholar author citation tracker: Is it too little, too late?”, Online Information Review, 36 (1): 126-141.

Jacsó, P. (2012b) "The problems with the subject categories schema in the EigenFactor database from the perspective of ranking journals by their prestige and impact", Online Information Review, 36 (5): 758-766.

Jacsó, P. (2012c) "Using Google Scholar for journal impact factors and the h-index in nationwide publishing assessments in academia-siren songs and air-raid sirens", Online Information Review, 36 (3): 462-478.

Kellner, A. W. and L. C. Ponciano (2008) "H-index in the Brazilian Academy of Sciences: Comments and concerns", Anais da Academia Brasileira de Ciências, 80 (4): 771781 . 
Kelly, C. D. and M. D. Jennions (2007) "H-index: Age and sex make it unreliable", Nature, 449 (7161): 403.

Kulkarni, A.V., B. Aziz, I. Shams and J.W. Busse (2009) "Comparisons of citations in Web of Science, Scopus and Google Scholar for articles published in general medical journals ", The Journal of the American Medical Association (JAMA), 302 (10): 1092-1096.

Lacasse, J. R. Hodge, D. R. and K. F. Bean (2011) "Evaluating the productivity of social work scholars using the h-index", Research on Social Work Practice, 21 (5): 599607.

Lazaridis, T. (2010) "Ranking university departments using the mean h-index". Scientometrics, 82 (2): 211-216.

Levine-Clark, M. and J. Kraus (2007) "Finding chemistry information using Google Scholar: A comparison with Chemical Abstracts Service", Science \& Technology Libraries, 27 (4): 3-17.

Leydesdorff, L. (2004) "Top-down decomposition of the Journal Citation Report of the Social Science Citation Index: Graph-and factor-analytical approaches". Scientometrics, 60 (2): 159-180.

Leydesdorff, L. and T. Opthof (2010) "Scopus's Source Normalized Impact per Paper (SNIP) versus a Journal Impact Factor based on fractional counting of citations" Journal of the American Society for Information Science and Technology (JASIST), 61 (11): 2365-2369.

Liu, J. S. and Y. Y. L. Lu, "An integrated approach for main path analysis: Development of the Hirsch index as an example" Journal of the American Society for Information Science and Technology (JASIST), 63 (3): 528-542.

Lopez-Illescas, C., F. Moya-Anegon and H.F. Moed (2008) "Coverage and citation impact of oncological journals in the Web of Science and Scopus", Journal of Informetrics, 2 (4): 304-316.

Losev, K.S. Efremovich, V.M. Kryuchkova, E.A. and V.K. Lyuboshchinskaya (2009) "Geography in the VINITI of the RAS: From reference journal to database. A history of development. Statistical characteristics during 1954-2008", Scientific and Technical Information Processing, 36 (4): 262-266.

Luciano, M. (2012) "The new impact factor and immediacy index of World Psychiatry", World Psychiatry, 11 (3): 207-208.

Lynn B.G. (2010) "IEEE Xplore", Online (Wilton, Connecticut), 34 (3): 26-28.

Ma, H. Ho, Y.-S. and H.-Z. Fu, (2011) "Solid waste related research in Science Citation Index Expanded" Archives of Environmental Science, 5: 89-100.

Magri, M.-H. and A. Solari (1996) "The SCI Journal Citation Reports: A potential tool for studying journals ? I. Description of the JCR journal population based on the number of citations received, number of source items, impact factor, immediacy index and cited half-life", Scientometrics, 35 (1): 93-117.

Maravić, B. (2005) "Directory of Open Access Journals ", Kemija u industriji / Journal of Chemists and Chemical Engineers, 54 (11): 482-483.

Markusova, V.A. (2008) "Publishing activity of Russian scientists according to SCI and Scopus databases", Scientific and Technical Information Processing, 35 (3): 120-127.

Mayr, P. and .-K. Walter (2007) "An exploratory study of Google Scholar", Online Information Review, 31 (6): 814-830. 
Meho, L.I. and K. Yang (2007) "A new era in citation and bibliometric analyses: Web of Science, Scopus, and Google Scholar", Journal of the American Society for Information Science and Technology (JASIST), 58 (13): 2015-2125.

Mikki, S. (2010) "Comparing Google Scholar and ISI Web of Science for Earth Sciences", Scientometrics, 82 (2): 321-331.

Mingers, J. and E.A.E.C.G. Lipitakis (2010) "Counting the citations: A comparison of Web of Science and Google Scholar in the field of business and management", Scientometrics, 85 (2): 613-625.

Moed, H. F. (2010) "A new journal citation impact measure that compensates for disparities in citation potential among research areas", Annals of Library and Information Studies (ALIS), 57 (3): 271-277.

Moed, H. F. (2011) "The source normalized impact per paper is a valid and sophisticated indicator of journal citation impact", Journal of the American Society for Information Science and Technology (JASIST), 62 (1): 211-213.

Moh, F.-Y. Lu, H.-P. and B.-H. Lin (2012) "Contributions to financial crisis research: An assessment of the literature in Social Science Citation Index journals from 1990 to 2008", Applied Economics, 44 (36): 4689-4700.

Morozova, O.P. (2008) "Internet coverage of the VINITI RAS", Scientific and Technical Information Processing, 35 (3): 153-154.

Moskovkin, V.M. (2009) "The potential of using the Google Scholar search engine for estimating the publication activities of universities", Scientific and Technical Information Processing, 36 (4): 198-202.

Moussa, S. and M. Touzani (2010) "Ranking marketing journals using the Google Scholar-based hg-index", Journal of Informetrics, 4 (1): 107-117.

Murphy, J. and R. Law (2008) "Google Scholar visibility and tourism journals ", Annals of Tourism Research, 35 (4): 1078-1082.

Nagaraja, A. and M. Vasanthakumar (2011) "Comparison of Web of Science and Scopus Impact Factors of Indian journals ”, Library Philosophy \& Practice, 14: Article no. 596: pp. 1-6.

Nair, G. M. and B. A. Turlach (2012) "Stochastic h-index", Journal of Informetrics, 6 (1): 80-87.

Norris, M. and C. Oppenheim (2010) "The h-index: A broad review of a new bibliometric indicator", Journal of Documentation, 66 (5): 681-705.

Noruzi, A. (2005) "Google Scholar: The new generation of citation indexes", Libri, 55 (4): $170-180$.

Ortner, H.M. (2010) "The impact factor and other performance measures - much used with little knowledge about", International Journal of Refractory Metals and Hard Materials, 28 (5): 559-566.

Pislyakov, V.V. (2009) "Comparing two "thermometers": Impact factors of 20 leading economic journals according to Journal Citation Reports and Scopus", Scientometrics, 79 (3): 541-550.

Quesada, A. (2009) "Monotonicity and the Hirsch index", Journal of Informetrics, 3 (2): $158-160$

Ristović, I., P. Dašić and J. Dašić (2014) “Analysis of the SCI, SCI-E and SSCI journals in the fields of mining transport, haulage and hoisting", Applied Mechanics and Materials, 683: 78-85. 
Rizkallah, J. and D.D. Sin (2010) "Integrative approach to quality assessment of medical journals using impact factor, Eigenfactor and Article influence scores", PLoS (Public Library of Science) One, 5 (4), Article no. e10204: pp. 1-10.

Rogers, M. (2007) "ProQuest CSA free marketing kit", Library Journal, 132 (6): 23-24.

Rousseau, R. (2007) "The influence of missing publications on the Hirsch index", Journal of Informetrics, 1 (1): 2-7.

Schreiber, M. (2010) "A new family of old Hirsch index variants", Journal of Informetrics, 4 (4): 647/651.

Shamaev, V.G. Zharov, A.V. and A.B. Gorshkov (2007) "Development of technology for the creation of retrospective reference databases of the VINITI RAN for physics and mathematics", Scientific and Technical Information Processing, 34 (1): 10-16.

Sidiropoulos, A. Katsaros, D. and Y. Manolopoulos (2006) "Generalized h-index for disclosing latent facts in citation networks", Scientometrics, 72 (2): 253-280.

Sillet, A. Katsahian, S. Rangé, H. Czernichow, S. and P. Bouchard (2012) "The Eigenfactor ${ }^{\mathrm{TM}}$ score in highly specific medical fields: The dental model", Journal of Dental Research (JDR), 91 (4): 329-333.

Sl. glasnik RS, br. 38/2008: Pravilnik o postupku i načinu vrednovanja i kvantitativnom iskazivanju naučno-istraživačkih rezultata istraživača.

Šipka, P. (2005) "The Serbian citation index: context and content", In: Proceedings of ISSI 2005, Stockholm: Karolinska University Press, pp. 710-711.

Su, X.-N., Han, X.-M. and X.-N. Han (2001) "Developing the Chinese Social Science Citation Index”, Online Information Review, 25 (6): 365-369.

Tol, R. S. J. (2009) "The h-index and its alternatives: An application to the 100 most prolific economists", Scientometrics, 80 (2): 317-324.

Tomer, C.A (1986) "Statistical assessment of two measures of citation: The impact factor and the immediacy index", Information Processing and Management, 22 (3): 251258.

Torres-Salinas, D., E.D. Lopez-Cózar and E. Jiménez-Contreras (2009) "Ranking of departments and researchers within a university using two different databases: Web of Science versus Scopus", Scientometrics, 80 (3): 761-774.

Toth, T. (1998) "Chemical Abstracts Service source of chemical information", Kemija u industriji / Journal of Chemists and Chemical Engineers, 47 (7/8): 265-274.

Van Raan, A. F. J. (2006) "Comparison of the Hirsch-index with standard bibliometric indicators and with peer judgement for 147 chemistry research groups", Scientometrics, 67 (3): 491-502.

Vanclay, J. K. (2008) "Ranking forestry journals using the h-index", Journal of Informetrics, 2 (4): 326-334.

Vieira, E.S. and J.A.N.F. Gomes (2009) "A comparison of Scopus and Web of Science for a typical university", Scientometrics, 81 (2): 587-600.

Vine, R. (2006) "Google Scholar", Journal of the Medical Library Association (JMLA), 94 (1): 97-99.

Walters, W.H. (2014) "Do Article Influence scores overestimate the citation impact of social science journals in subfields that are related to higher-impact natural science disciplines?" Journal of Informetrics, 8 (2): 421-430.

Ward, J. (2014) "Prestige versus citation volume as journal indices in cognitive neuroscience", Cognitive neuroscience, 5 (3-4): 135-37.

West, J. D. (2008) "Eigenfactor: Pulling the stories out of the data"; Research Trends, (8): 8. 
West, J. D. (2010) "Eigenfactor: Ranking and mapping scientific knowledge" Ph.D. Dissertation. Seattle (Washington - USA): University of Washington, 2010. pp. 139.

Wu, J. Lozano, S. and D. Helbing (2011) "Empirical study of the growth dynamics in real career h-index sequences", Journal of Informetrics, 5 (4): 489-497.

Yin, C.-Y. (2011) "Do impact factor, h-index and Eigenfactor of chemical engineering journals correlate well with each other and indicate the journals ' influence and prestige?" Current Science, 100 (5): 648-653.

Yue, W. Wilson, C. S. and R. Rousseau (2004) "The immediacy index and the journal impact factor: Two highly correlated derived measures", The Canadian Journal of Information and Library Science, 28 (1): 33-48.

Zhang, C.-T. (2010) "Relationship of the h-index, g-index and e-index", Journal of the American Society for Information Science and Technology (JASIST), 61 (3): 625-628.

Zhiren, Z. (2002) "On the characteristic Chinese database: Chinese Social Science Citation Index", Journal of Information, Communication and Library Science, 9 (1): 57-61.

Zibareva, I.V. and N.S. Soloshenko (2011) "Russian scientific publications 2005-2009 in the Science Citation Index, Scopus and Chemical Abstracts databases", Scientific and Technical Information Processing, 38 (3): 212-223.

\section{Abbreviations:}

\begin{tabular}{|c|c|c|c|}
\hline $5 \mathrm{YIF}$ & Five-Year Impact Factor & II & Immediacy Index \\
\hline$\% \mathrm{ACI}$ & $\%$ Articles in Citable Items & IPP & Impact per Publication \\
\hline$\% \mathrm{IC}$ & $\%$ International Collaboration & JCR & Journal Citation Report \\
\hline$\% \mathrm{NC}$ & $\%$ Not Cited & JIF & Journal Impact Factor \\
\hline $\mathrm{A}$ & Articles & MedIF & Median Impact Factor \\
\hline $\mathrm{A} \& \mathrm{HCI}$ & $\begin{array}{l}\text { Arts \& Humanities Citation } \\
\text { Index }\end{array}$ & MIF & Mean Impact Factor \\
\hline AggIF & Aggregate Impact Factor & $\mathrm{NEF}$ & $\begin{array}{l}\text { Normalized Eigenfactor or } \\
\text { Normalized Eigenfactor Score }\end{array}$ \\
\hline AggII & Aggregate Immediacy Index & NoJ & Number of Journals \\
\hline AI & $\begin{array}{l}\text { Article Influence or Article } \\
\text { Influence Score }\end{array}$ & QiC & Quartile in Category \\
\hline $\mathrm{CDB}$ & Citation DataBase & $\mathrm{RiC}$ & Rank in Category \\
\hline CGI & Cumulative Growth Index & SCI & Science Citation Index \\
\hline CHL & Cited Half Life & SCI-E & $\begin{array}{l}\text { Science Citation Index } \\
\text { Expanded }\end{array}$ \\
\hline $\mathrm{CI}$ & Citable Items & SJR & SCImago Journal Rank \\
\hline CngHL & Citing Half Life & SNIP & $\begin{array}{l}\text { Source Normalized Impact } \\
\text { per Paper }\end{array}$ \\
\hline $\mathrm{EF}$ & $\begin{array}{l}\text { Eigenfactor or Eigenfactor } \\
\text { Score }\end{array}$ & SSCI & Social Science Citation Index \\
\hline h-index & Hirsch Index & $\mathrm{TC}$ & Total Cites or Total Citations \\
\hline IFwJSC & $\begin{array}{l}\text { Impact Factor only with } \\
\text { Journal Self Cites }\end{array}$ & WoS & Web of Science \\
\hline IFwoJSC & $\begin{array}{l}\text { Impact Factor without Journal } \\
\text { Self Cites }\end{array}$ & & \\
\hline
\end{tabular}




\section{STANJE I ANALIZA NAUČNIH JOURNALS U OBLASTI "EKONOMSKIH NAUKA" ZA PERIOD 1995-2014.}

Apstrakt: SCI-E and SSCI su jedne od glavnih citatnih baza podataka (Citation Databases - CDB) u svetu u oblasti prirodnih i primenjenih (SCI-E) i socijalnih (SSCI) naučnih disciplina. Za 2014. godinu, unutar SCI-E sve naučne oblasti prirodnih i primenjenih naučnih disciplina razvrstane su u 176 kategorija, a unutar SSCI sve naučne oblasti socijalnih naučnih disciplina razvrstane su u 56 kategorija. Naučni časopisi u oblasti "Ekonomskih nauka" razvrstani su unutar SSCI u 8 kategorija, plus jedna kategorija unutar SCI-E. Cilj rada je da se prikaže stanje i analiza naučnih časopisa indeksiranih u SSCI and SCI-E citatnim bazama podataka (CDB) za 9 (devet) navedenih kategorija u oblasti "Ekonomskih nauka" za period 1995-2014. Broj različitih naučnih časopisa za 9 (devet) navedenih kategorija u oblasti "Ekonomskih nauka", za period 1997-2014, povećao se za 445 časopisa (od 415 časopisa u 1997 do 860 časopisa u 2014) sa indeksom kumulativnog rasta (CGI) od $207,23 \%$ u odnosu na 1997. Najbolje rangirana kategorija od navedenih devet u oblasti "Ekonomskih nauka" bila je kategorija "Economics" / "Ekonomija" (Econ), koja je prema broju časopisa za ceo period 1995-2014, uvek bila rangirana kao prva (top-jedan) u okviru SSCI. Najveće povećanje broja naučnih časopisa za period 1995-2014 za svih devet navedenih kategorija u oblasti "Ekonomskih nauka" imala je kategorija "Management" / "Menadžment" (Manag).

Ključne reči: Bibliometrijska analiza, citatna baza podataka (CDB), citatni indeks za socijalne nauke (SSCI), impakt faktor časopisa (JIF), "Ekonomske nauke". 